\title{
Quantitative Risk Assessment of Environmental Hazards Generated by a Tailings Embankment: case study Cabeço do Pião, Portugal
}

\author{
A. Fiúza, A. Leite, M. Vila, M.L. Dinis, A. Futuro, J. Gois y J. Figueiredo \\ Centro de Recursos Naturais e Ambiente (CERENA), Faculty of Engineering, University of Porto, Rua Dr. Roberto Frias s/n, \\ 4200-465 Porto, Portugal
}

\begin{abstract}
The Panasqueira mine is a world-class tungsten mine and probably one of the most important in Europe, having been continuously in operation since 1898. Between 1927 and 1996, the ore was fully or partially processed in a processing plant located on the left bank of the Zêzere River. The tailings were stored along the bank, in an extension of about $1.5 \mathrm{~km}$. The fine particles, locally known as 'sludge', were stored in a self-constructed embankment located on a steep hillside. The current average slope is about $36^{\circ}$. The sludge has high concentrations of some heavy metals $(\mathrm{Cu}, \mathrm{Zn}, \mathrm{W}$ and $\mathrm{Cd}$ ) but has a particularly high concentration in arsenic (about 15\%). This tailings storage was not included in the National Plan for Rehabilitation of Abandoned Mines, despite presenting a high environmental risk.

A quantitative environmental risk assessment characterises this situation, considering two possible alternatives: the current state with continuous release of contaminants or, alternatively, the situation that would arise from an eventual collapse of the storage embankment. In the first situation, we used a classical methodology of risk assessment to estimate the concentrations of arsenic in the affected compartments using a conservative exposure scenario and inferring the doses to which the local population is subjected. These doses are compared with reference acceptable values. In the second situation, the creation of a dispersed source of contamination encompasses a much higher dispersion area, a larger population and more expensive rehabilitation costs.
\end{abstract}

Keywords: environmental risk assessment; tailings embankment; arsenic; geochemistry.

\section{Evaluación Cuantitativa de Riesgos Ambientales Generados por Una Presa de Relaves: caso de estudio Cabeço do Pião, Portugal}

\begin{abstract}
RESUMEN
Desde 1898, Panasqueira es una de las principales minas de tungsteno del mundo, y probablemente la más importante de Europa, habiendo estado continuamente en exploración. Entre 1927 y 1996 los minerales fueron procesados en una planta metalúrgica en las orillas del río Zêzere. Los relaves de este tratamiento se almacenaban a lo largo de la margen izquierda del río, en una extensión de aproximadamente $1.5 \mathrm{~km}$. Las partículas finas ('lodos'), se almacenaron en una presa autoconstruida situado en una ladera que ya tenía originalmente una elevada pendiente. La pendiente media actual es de unos $36^{\circ}$. Los lodos tienen altas concentraciones en algunos metales pesados, siendo muy alta en arsénico (alrededor del 15\% en peso). Este depósito de relaves no fue incluido en el Plan Nacional de Rehabilitación de Minas Abandonadas, a pesar de presentar un alto riesgo ambiental.

Para cuantificar esta circunstancia, se preparó una evaluación cuantitativa del riesgo ambiental, teniendo en cuenta dos posibles situaciones: la actual, con liberación continua de contaminantes y, alternativamente, la situación que se derivaría del colapso de la presa. En la primera situación, se utilizó una metodología clásica de análisis cuantitativo del riesgo ambiental, estimando las concentraciones de arsénico en los compartimentos afectados utilizando un escenario de exposición conservador para inferir las dosis a las que está sujeta la población local. En la segunda situación resultaría la creación de una fuente dispersa de contaminación abar-
\end{abstract}


Fiúza, A., et al, 2021. Quantitative Risk Assessment of Environmental Hazards Generated by a Tailing Embankment..., 132 (4): $465-486$

cando un área de influencia mucho más alta, una población más grande y mayores costos de rehabilitación.

Palabras clave: Evaluación de riesgos ambiental, presa de relaves, arsénico, geoquímica.

\section{VERSIÓN ABREVIADA EN CASTELLANO}

Este artículo presenta un Análisis Cuantitativo de Riesgo Ambiental y Toxicológico (ACRAT) sobre el almacenamiento de 'lodos' (relaves del proceso de tratamiento de minerales con granulometría fina) existentes en el sitio llamado Cabeço do Pião y que fueron producidos por una planta de tratamiento de minerales que allí operó entre 1927 y 1996 y que desde entonces ha sido abandonada.

Los lodos almacenados (alrededor de 730000 m3) son constituidos por varios minerales, muchos de los cuales existen en forma de sulfuros, especialmente piritas y arsenopyrite. Por acción del oxígeno y del agua, y en algunos casos por acción microbiana, los sulfuros se oxidan progresivamente a sulfatos, liberando ácido que a su vez lixivia algunos de los metales presentes. En el proceso de oxidación de sulfuros de hierro, los óxidos de hierro-hidróxidos se forman como un producto final.

Los lixiviados se producen en el almacenamiento de relaves y se liberan en la pendiente, en una zona de resurgimiento, inmediatamente por debajo de la presa de apoyo fluyendo a la base de la encosta, donde una fracción de estos lixiviados se diluye por la mezcla en el río y otra parte es sorbida por los óxidos e hidróxidos de hierro formados.

Los relaves almacenados tienen altas concentraciones en algunos metales pesados, a saber, en arsénico, zinc, cobre y tungsteno. Por lo tanto, existe una liberación continua de contaminantes, y el arsénico es tan dominante, debido al alto contenido de los relaves en arsenopirita, que los otros contam

inantes pueden ser ignorados comparativamente. Además de esta liberación, acrece la acción eólica porque los residuos están directamente expuestos a la atmósfera, sin ninguna cubierta. Los dos vectores dispersivos, el agua y el aire, son responsables del transporte y destino de contaminantes que se distribuyen por los distintos compartimentos ambientales.

Gran parte de la información producida en el marco de un proyecto europeo Era-Min (Remine) se utilizó en este estudio. El inventario de los relaves existentes fue realizado por un dron y digitalizando la topografía original. La presa de deposición se muestreó mecánicamente y se obtuvieron 80 muestras a diferentes profundidades. Esta información se complementó con seis perforaciones que ya se habían realizado anteriormente, así como mediante un estudio geofísico utilizando un radar penetrante de los suelos. Por lo tanto, fue posible construir un modelo conceptual de la presa de almacenamiento y estimar los volúmenes de los diferentes materiales almacenados. Este modelo asociado con los datos meteorológicos del sitio permitió establecer un balance hídrico y el régimen circulante del agua infiltrada a través de la presa.

Las muestras recogidas permitieron la caracterización física (densidades, porosidad, distribución granulométrica), química (composición química, mineralógica y $\mathrm{pH}$ ) y ambiental (lixiviación natural y producción de ácidos). La distribución espacial de las concentraciones de los principales elementos potencialmente contaminantes fue estudiada por métodos geo-estadísticos. También se determinaron otros parámetros relevantes, como la composición y la concentración de lixiviados y la concentración y distribución espacial del polvo.

Al mismo tiempo, existían numerosos estudios publicados sobre el estado de contaminación de los diversos compartimentos ambientales: aguas superficiales y subterráneas, suelos, polvos, y flora. Sin embargo, estos estudios nunca se habían combinado en un enfoque integrado, que permitiese una visión general sistémica destinada a evaluar cuantitativamente el riesgo ambiental resultante de la existencia de este almacenamiento de residuos.

Además de estos riesgos, que actualmente se colocan continuamente, motivados por la erosión física y química de la presa, también existe la posibilidad de un escenario de catástrofe - la ruptura parcial del almacenamiento los relaves por picos de lluvias intensas y/o acción sísmica, aunque esta última con una probabilidad muy baja de ocurrencia.

En la ejecución del análisis de riesgo, se utilizó una metodología clásica, estudiando la fuente de contaminación, los mecanismos de liberación, el transporte y destino de contaminantes, las características de los medios de receptores, un escenario de exposición de la población a estos, la determinación de las dosis resultantes de dicha exposición y, por último, el cálculo de los parámetros toxicológicos que permiten evaluar cuantitativamente las consecuencias de la situación.

Se consideraron dos escenarios. En el primero, el riesgo ambiental y toxicológico resultante de la situación actual se evaluó cuantitativamente utilizando, en la medida de lo posible, modelos matemáticos para estimar las concentraciones en los medios receptores, comparándolas con los valores medidos. Adoptando un escenario normalizado de exposición de la población a los medios receptores, se estimaron las dosis resultantes de esta exposición y, por último, se evaluaron los riesgos toxicológicos y carcinógenos utilizando la información de la base de datos IRIS, recomendado por la EPA (Environmental Protection Agency) para estudios ambientales de este tipo.

El arsénico fui considerado el único contaminante importante. Se consideró que la exposición de la población local se producía por ingestión (consumo 
de agua, ingestión de suelos, verduras y consumo de pescado), inhalación de polvo y contacto dérmico con el polvo de la atmósfera. Los valores obtenidos nos permitieron inferir, que existen altos riesgos para la salud humana, en las perspectivas tóxicas y cancerígenas, para las exposiciones por ingestión y por contacto dérmico, siendo la exposición por inhalación aceptable.

En el segundo escenario, se consideró una situación catastrófica con ruptura parcial de la presa de almacenamiento, en que se añade a el escenario anterior la liberación de un volumen considerable de fase líquida (ácido lixiviado con alta concentración en arsénico) y fase sólida, el 'lodo' que sería dispersado por grandes áreas en la zona ribereña del río Zêzere. Se caracterizó el tipo más probable de ruptura, se estimó los volúmenes de residuos y lixiviados que se liberarían, así como la zona que se vería afectada por el derrame.

\section{Introduction}

The fundamental concepts for Environmental Risk Assessment were created by the U.S. National Academy of Sciences that suggested a four-stage process (LaGrega et al., 1994): a) Hazard identification; b) Exposure assessment; c) Toxicity assessment; d) Risk characterisation.

The concept was first applied by the Environmental Protection Agency (EPA) in 1984 for carcinogens (LaGrega et al., 1994), issuing carcinogenic potency factors (CPFs) that could be used in predictive models to estimate the carcinogenic risk of potentially exposed populations. A similar approach was later applied to non-carcinogens by setting acceptable daily intake levels, later replaced by reference doses (RfDs).

When contaminants are released into the environment, they may reach damaging concentrations. The concentration at the target is called exposure. The product of exposure with the specific conditions of exposure (rate of breathed air, daily intake of water,...) is called the dose. The relationship between dose and its damage, quantified by the RfDs or by the CPFs, is the risk.

Risks for non-carcinogens are assessed by the ratio between the "predicted environmental concentration" and the "predicted no-effect concentration", or reference dose. This ratio is commonl known as the toxicity index, and should be lower than one. For carcinogens, risk is the product of the predicted environmental concentration by the CPF and represents the incremental risk caused by that particular source that adds to the background one.

The estimation of environmental exposure has the following purposes (Wagner and Matthies, 1996): a) to determine concentrations in relevant environmental compartments; b) to understand the transport and fate processes; and, c) to identify endangered populations.

The mathematical models used to assess environ- mental exposure are developed through several steps (Trapp and Matthies, 1998): a) definition of purpose and scope; b) identification of underlying physical, chemical and biological processes; c) formulation of mathematical equations that will be used in the model; d) data acquisition; e) verification and calibration of the model structure; f) sensitivity analysis.

This paper presents a partial Quantitative Environmental Risk Analysis for Human Health resulting from the storage of fine mine tailings ('sludge') existing at the site called Cabeço do Pião, near the active Panasqueira Mine, constituted by waste produced by a former ore processing facility, which ran in the site between 1927 and 1996, and which has been abandoned ever since. Several minerals constitute the stored sludge (about 730,000 $\mathrm{m}^{3}$ ), many of which occur in the form of sulphides, especially pyrite and arsenopyrite. By the action of oxygen and water, and in some cases by microbial action, the sulphides have been progressively oxidised into sulphates, releasing hydronium cation, which in turn has leached some of the metals present. The tailings embankment affects the local environment by aquatic transport and transformation of the leachates, the spread of dust by the wind and by the risk of failure of the embankment.

Numerous surveys exist which describe the state of contamination of the various environmental compartments - surface and groundwater, soil, dust and flora (Candeias, 2015, Ferreira da Silva, 2013, Candeias C ${ }^{\mathrm{a}, \mathrm{c}}$, 2014, Avila, 2016). However, these studies have never been linked in an integrated approach, allowing for a global systemic view that aims to evaluate quantitatively the environmental and human health risks resulting from the existence of this waste storage.

The conceptual foundation behind environmental risk assessment has been subjected to many criticisms, the most important being the following: the results of quantitative risk assessment may not be subject to validation by observation (Brown, 1985). Assessment of the risk is difficult (a) because the exposure is usually well below levels at which lethal toxic effects and even sub-lethal effects can be measured with statistical significance against the "noise" of natural population variation, and (b) because of the simultaneous multiple toxic influences of other substances, some taken voluntarily and others involuntarily (MacKay, 2001).

The risk assessment is not an end in itself, but a process to develop policies that make the best use of resources to protect the health of the public and of ecosystems (US EPA, 2014) and an important tool to support decision quantitatively.

Abandoned tailing embankments represent in many cases environmental risks of great environmental concern, potentially affecting human health and ecosystems. Surprisingly, quantitative environmental assessment has not yet been applied to these situations, although this tool may represent an important aid for the decision-maker who is helping to establish 
the priorities of remediation.

\section{Objectives}

The main objective of the research was to integrate all the information that was explicitly produced within the European Era-Min Project (Remine, 2019), with existing and published former studies, in order to assess the environmental and human health risk derived from the existence of this particular mine tailings storage. A classical methodology was used (Fjeld, 2007; Trapp 1997), considering the following steps: assessment of the release of the contaminants, the definition of the liberation mechanisms, transport and destination, characterisation of the intermediate receiving media, formulation of an exposure scenario and, finally, the assessment of the resulting doses and final quantification of the environmental toxicological ratios, using the EPA database for environmental studies of this type (US EPA, 2013).

As stated, we considered two different risk alternatives. For the first, we assessed the environmental risk that results from the present situation. For the second, we considered a catastrophic situation with partial failure of the tailings embankment. In this case, the release of a considerable volume of pulp was considered, with high concentrations in arsenic in both phases that would be dispersed through vast areas in the riparian zone of the Zêzere River.

Whenever possible, concentrations in the environmental compartments that were measured under the research developed within the REMINE Project (Remine, 2019) or published by other researchers who have devoted their attention to this relevant environmental problem, were used. Sometimes there are gaps in information that cannot be filled without making new studies which would forcibly be lengthy. Appropriate mathematical models were used to estimate the spatial and temporal distribution of the concentrations, with very conservative values for the uncertain parameters.

\section{Area of study}

The Panasqueira Mine, in Portugal, has ben exploited for wolframite, cassiterite and, chalcopyrite (W, Sn, $\mathrm{Cu}$ ), the latter two as by-products (Reis C., 1972; Sá, 1999) since 1898. Until 1912 the mining scale was very small, but it increased up to 1928 and finally became a large exploitation (Sá, 1999). One of the seven areas of exploitation was the Cabeço do Pião where the tailings were deposited from 1927 to 1996 (Sá, 1999). The waste was produced by one of the three processing plants that existed at the mine, the Rio or Cabeço do Pião Processing Plant (Sá, 1999). The location is the following: Latitude: $40^{\circ} 07^{\prime} 32.71^{\prime \prime} \mathrm{N}$ and longitude: $7^{\circ}$ $42^{\prime} 51.18^{\prime \prime} \mathrm{W}$. The local topography in the area ranges from 350 to $1,080 \mathrm{~m}$, with deep valleys. The streams are generally dry in summer and flooded during the winter. The climate is aggressive in the region, hot and dry during the summer and cold, rainy and windy in the winter. The average annual rainfall is $1,600 \mathrm{~mm}$. Snow frequently falls above the altitude of $700 \mathrm{~m}$. The average annual temperature is $12^{\circ} \mathrm{C}$, with values ranging from $0^{\circ} \mathrm{C}$ in the winter to about $30^{\circ} \mathrm{C}$ in summer (Gonçalves, 2014).

\section{The Panasqueira ore deposit}

The Panasqueira ore deposit is a typical example of a Sn-W hydrothermal mineralisation associated with the Hercynian plutonism (Noronha, 1992). The mineralised zone has an average length of $2,500 \mathrm{~m}$, a width ranging from 400 to $2,200 \mathrm{~m}$ and extends at least 500 $\mathrm{m}$ in depth. The Panasqueira Mine has been active for over 100 years and is one of the largest economic wolfram vein deposits in the world (Franco, 2014). During the period 1934-2016 it produced 128,110 t of tungsten concentrate, $6,576 \mathrm{t}$ of tin concentrate and 32,410 t of copper concentrate (data supplied by LNEG). The Panasqueira deposit consists of a series of stacked, sub-horizontal, hydrothermal quartz veins intruding into the Beira schists and shales. The paragenesis is complex and four stages of mineral formation are generally accepted (Noronha, 1992):

- The oxide and silicate formation stage: the most important stage from an economic point of view because it is when the formation of wolframite and cassiterite occurs and also the formation of quartz, muscovite, tourmaline, topaz and a large part of the arsenopyrite (in 2 phases);

- The sulphide formation stage: mainly the formation of sulphides, namely pyrite, chalcopyrite, sphalerite and pyrrhotite and the occurrence of a new generation of quartz, muscovite and arsenopyrite.

- The pyrrhotite alteration stage: a large amount of siderite and marcasite were formed, due to the iron released in the alteration process of the pyrrhotite and some pyrite. A new generation of pyrite occurred; some magnetite, hematite, galena, stannite and chalcopyrite were formed;

The commonest minerals found are quartz, wolframite, pyrite, pyrrhotite, arsenopyrite, chalcopyrite, cassiterite, beryl, mica and fluorite.

During its lifetime, three processing plants were used: Panasqueira, Cabeço do Pião and Barroca Grande. The construction of the Panasqueira Plant began in the 19th century and was progressively transferred, from 1928 onwards, to the Barroca Grande Plant which has a more central location, more available area, greater access to water and other advantages that led to its deactivation in the 1960s (Sá, 1999). As already commented, the Rio processing plant was built in 1927. With the abandonment of the exploitation of the Panasqueira vein, and due to the greater availability of water of the Zêzere River, this plant only treated the pre-concentrates that came, first by aerial 
cable and later by truck from the Barroca Grande Plant (Reis C., 1971). At the end of the 1980s, the Panasqueira mine had enough extension so that the drainage water was sufficient to supply the necessary flow to the entire industrial structure. For this reason, but also in order to rationalise costs and minimise the environmental impact, the centralisation of all the ore processing operations was carried out in the Barroca Grande between 1992 and 1996 (Reis C., 1971).

In the old industrial zone of Cabeço do Pião, on the slope of the left bank of the River Zêzere, two types of mining waste are stored (Fig. 1):

a. Coarse tailings originating from the former processing plant, either in a rake classifier or as tailings from shaking tables. This waste occupies an extension of $1.5 \mathrm{~km}$ on the slope, extending into a non-uniform distribution from the processing plant area to the sludge embankment. It contains low levels of heavy metals and sulphides with a reduced potential environmental impact (Silva, 2010).

b. Fine tailings, commonly referred to as 'sludge', consisting of depressed material from flotation cells, or overflow of cyclones, with high levels of heavy metals and sulphides, with a very high potential for a negative environmental impact. Its storage area, locally called "Sludge Embankment", was auto-constructed, taking advantage of the topography of the site, and using the coarse waste to create the supporting wall of the embankment (Reis C., 1971).

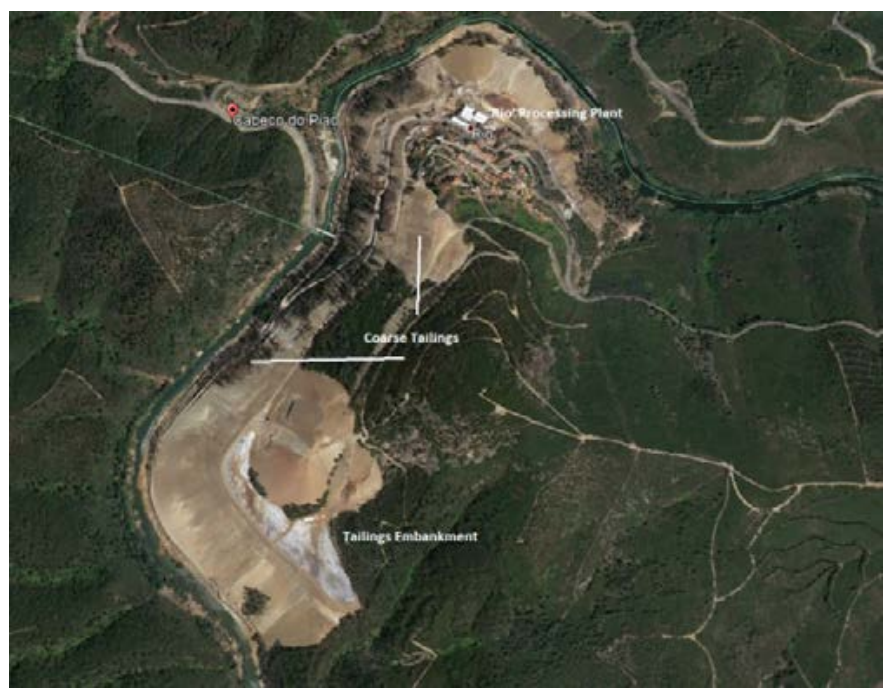

Figure 1. The tailings embankment area (Google view).

Figura 1. Vista da área de la presa de relaves.

\section{Methodology}

\section{Estimated volume of the deposit}

The volume of the deposit was estimated by the difference between the current topography and the one existing before the deposition of the tailings (Salom,
2017). Therefore, it includes not only the sludge, but also the retaining walls of the dam and the material used for the smoothing of shapes, which is essentially sandy material. It also took into consideration an ancient drilling campaign (Gama, 2002) and a GPR survey previously made at the site (Silva, 2010).

The following methodology was used (Remine, 2019):

- Firstly the original topography of the site (before the construction of the dam) was digitalised from an old map of the mining company that operated at the site.

- From this scan a three-dimensional model of the original topography was built.

- A drone was programmed for a flight path over the site, with photogrammetric data acquisition using a series of georeferenced points with high precision GPS.

- From this data it was possible to produce a 3D numerical model of the current topography of the tailings dam (Fig. 2);

- Combining the two above-mentioned models it became possible to build a 3D model of the rejected storage and from these calculate the volume of material existing on the site.

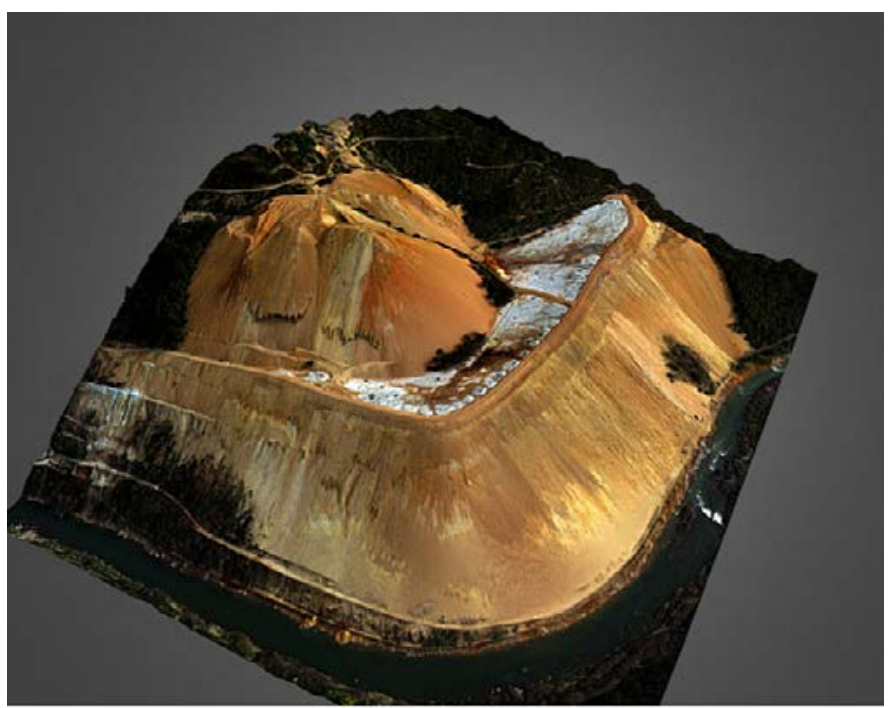

Figure 2. Tri-dimensional model of the sludge storage in the tailings dams. Figura 2. Modelo tridimensional del almacenamiento de lodos en la presa de relaves.

\section{Sampling of the tailings}

A sampling plan was carried out considering a sampling grid with dimensions of $40 \times 20 \mathrm{~m}$ (Salom, 2017, Gois, 2018). A total of eighty samples were collected, with 40 'superficial' (20 to $30 \mathrm{~cm}$ deep) and the remaining 40 with an average depth slightly greater than $1.5 \mathrm{~m}$. The samples were collected by digging using a mechanical excavator with an articulated arm. Coordinates of each sample were measured. 


\section{Methods for the physical, chemical and environmen- tal characterisation of the tailings}

The following parameters physically characterised the samples: volumetric mass density and porosity, both according to standard EN 1097-4:2008 (Comité Européen de Normalisation, 2008) and the grain size distribution measured by a Malvern Mastersizer 2000 particle size analyser using laser diffraction. The settling velocity of the particles was estimated from the former data using Stoke's law with correction for hindered settling (Major, 1998).

The following parameters were used for the chemical characterisation of the samples: chemical composition of tailings and 'sand', mineral composition by X-ray diffraction (Granjeia et al., 2011) and pH. The chemical composition was assessed by analysing all the 80 samples by energy dispersive $X$-ray fluorescence (Oxford Instruments X-MET 7500, mining mode). The mineral composition was not specifically determined in the Remine project as it did exist in former studies published by Granjeia (2011). The $\mathrm{pH}$ of the tailings was measured in water and with $\mathrm{CaCl}_{2}$ (Minasny, 2011).

For the environmental characterisation of the samples the following two tests were carried out: natural leaching with water and tests of acid generation. The first tests followed the standard DIN38414-S4 and the second ones followed procedures defined by Coastech, 1999.

\section{Atmospheric dispersion - assessment method}

The particle deposition flux was assessed in the surrounding area of Cabeço do Pião using sedimentation plates for dust collection, according to the French standard NF X43-007 (1973). Sedimentation plates are made of stainless steel, with an area of $50 \mathrm{~cm}^{2}$. They are fixed to masts in places where the coordinates are measured. A layer of silicone (polydimethylsiloxane), that captures the settled dust, covers their surface. The plates remain at the chosen location for a long time, usually one or more months, after which they are collected.

In the laboratory the silicone layer is dissolved and the mass of dust collected is weighted, allowing for assessing the depositional flux $\left(\mu \mathrm{g} \mathrm{m}^{-2} \mathrm{~h}^{-1}\right)$, represented by the letter J. From the flux and knowing the settling velocity of particle deposition $u(\mathrm{~m} / \mathrm{h})$ it is possible to estimate the average concentration of dust in the atmosphere $\left(\mathrm{\mu g} \mathrm{m}^{-3}\right)$ (equation 1).

$$
C\left(\mu g m^{-3}\right)=\frac{J\left(\mu g m^{-2} h^{-1}\right)}{u\left(m h^{-1}\right)}
$$

Two campaigns of dust collection were executed: one in February and March and another in June-July 2018. As expected, the deposition flux in the winter season was lower than the flow observed during the summer period.

\section{Quantitative risk assessment of environmental ha- zards generated by a tailings embankment}

The quantitative risk assessment of environmental hazards generated by the tailings embankment was elaborated according to the following methodology (representative scheme shown in Fig. 3): a) characterisation of the source, including a survey of the initial (or reference) state; this includes the selection of the hazardous elements based on toxicology and legislation; b) mechanisms of liberation (leaching, wind and dust); c) mechanisms of transport or dispersive vectors (air,

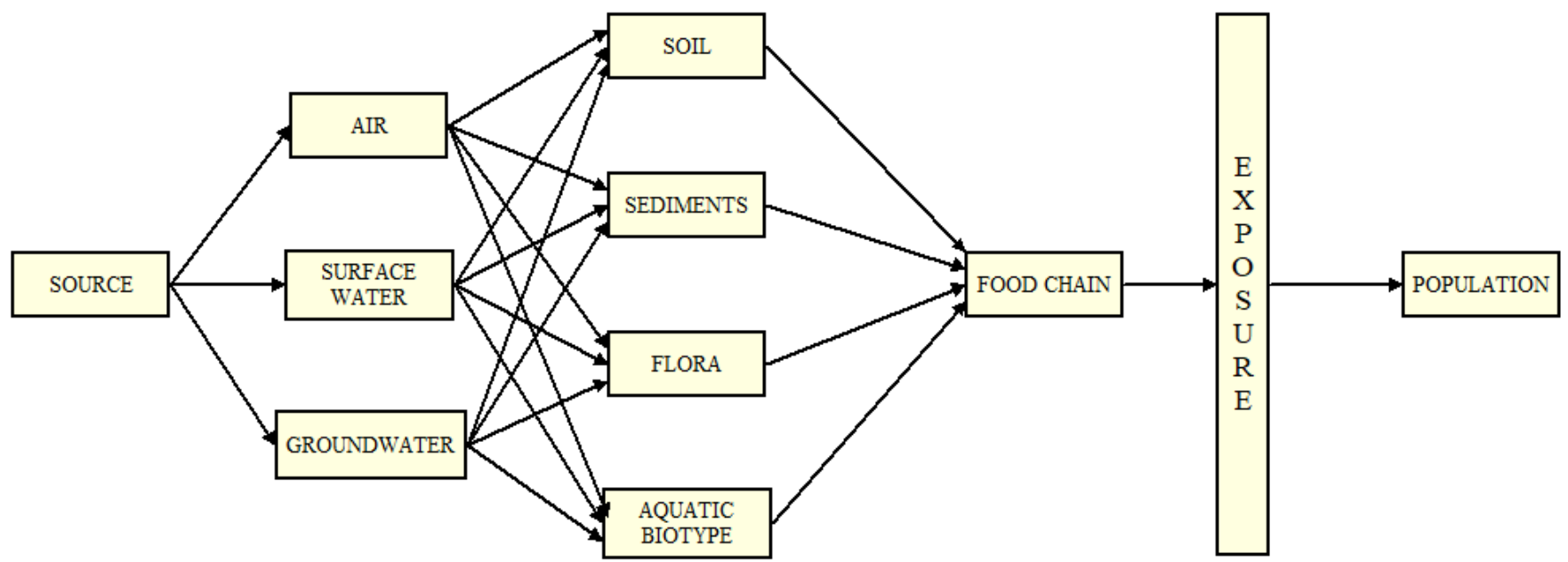

\begin{tabular}{l|l} 
SOURCES & TRANSPORT AND FATE \\
\hline
\end{tabular}

RECEPTORS

SCENARIO

DOSES

Figure 3. General scheme of a Quantitative Environmental Risk Assessment.

Figura 3. Esquema general de una evaluación cuantitativa del riesgo ambiental. 
surface water, groundwater); d) mechanisms of transfer to environmental compartments (sorption, deposition, degradation,...); e) assessment of concentrations within each environmental compartment using models of environmental dispersion; $f$ ) inventory of the exposed sites (wells, inhabited areas); g) identification of receiving agents (local water consumers, population, special groups, ...); h) selection of standardised exposure scenarios of the population to contaminated sites; i) determination of doses for each exposure pathway (ingestion, inhalation and dermal contact).

\section{Characterisation of the contamination source}

The characterisation of the source included the following aspects:

a) a survey of the former mining area based on an environmental perspective;

b) an estimation of the tailings volume;

c) sampling of the tailings;

d) physical, chemical and environmental characterisation of the tailings;

e) climate, hydrological cycle and model of water circulation;

f) quantification of hazardous elements existing in the embankment;

g) oxidation of sulphides and formation of acid mining drainage;

h) considerations regarding structural stability and risk of rupture.

\section{Quantification of stored material}

The following quantification of the deposit was obtained: stored volume of ' sludge', 730,000 $\mathrm{m}^{3}$; total volume of the storage area, including supporting walls, $1200,000 \mathrm{~m}^{3}$; total volume of material deposed compared to the original topography, $2630,000 \mathrm{~m}^{3}$. We can conclude that about $61 \%$ of the material existing in the storage area is made up of fine tailings, whilst the remaining $39 \%$ was used to build the support wall and for smoothing the topography.

\section{Physical characterisation of the tailings}

The total average wet density was 2.23 whilst the bulk (dry) density had an average value of $1.27 \mathrm{~g} / \mathrm{cm}^{3}$. The average porosity was $50 \%$ whilst the average particle density was $3.43 \mathrm{~g} \mathrm{~cm}^{-3}$. Figure 4 represents the grain size distribution of different superficial and deep samples (Figueiredo, 2019). There is an evident heterogeneity, although the silt fraction is always prevalent in all the samples.

The grain size becomes slightly finer with depth and the overall weighted median grain size is $26 \mu \mathrm{m}$ For this median grain size, the settling velocity is $5.37 \mathrm{~cm} / \mathrm{s}$.

Table 1 shows an example of average values for a superficial and for a deep sample, as well as the respective values for the uniformity and curvature parameters.

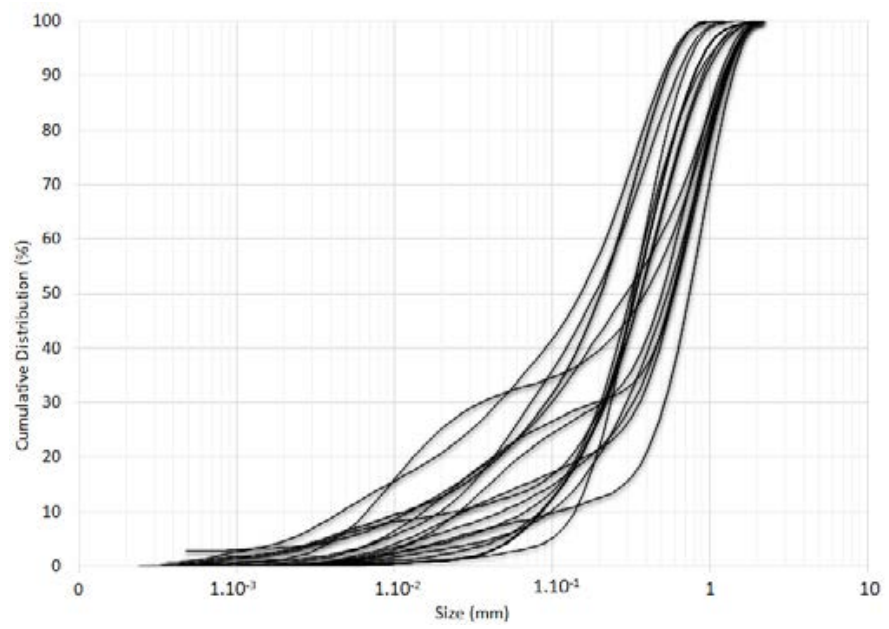

Figure 4. Particle size distribution of different superficial and deep samples.

Figura 4. Distribución del tamaño de partícula de diferentes muestras superficiales y profundas.

$\begin{array}{lcc}\text { Parameter } & \text { Superficial S. } & \text { Deep S. } \\ \mathrm{D}_{10}(\mu \mathrm{m}) & 8.2 & 3 \\ \mathrm{D}_{30}(\mu \mathrm{m}) & 20 & 7 \\ \mathrm{D}_{50}(\mu \mathrm{m}) & 37 & 12 \\ \mathrm{D}_{60}(\mu \mathrm{m}) & 45 & 15 \\ \text { Coefficient of uniformity } & 5.49 & 5.00 \\ \text { Coefficient of curvature } & 1.08 & 1.09\end{array}$

Table 1. Typical grain sizes and coefficients for an average superficial sample and a deep sample.

Tabla 1. Tamaños y coeficientes de granos típicos para una muestra superficial y profunda promedio.

\section{Chemical characterisation of the tailings}

\section{Chemical composition}

All the samples showed an acidic $\mathrm{pH}$ varying from 1.4 to 3.6. However, the 'superficial' samples have a lower $\mathrm{pH}$ than the 'deeper' ones. The most intense acidity of the superficial samples is attributed to the oxidation of the existing sulphide minerals by the interaction with the atmosphere, thus evidencing their characteristic behaviour as acid producers.

The chemical composition of the samples is shown in Table 2. Other elements that did not have significant concentrations were also analysed and had grades below or near the detection threshold $(\mathrm{Ga}, \mathrm{Ge}$, Mo, $\mathrm{Ag}, \mathrm{In}, \mathrm{Au}$ and $\mathrm{Pb}$ ).

The following minerals were found (Grangeia et al. 2011): quartz, mica, feldspar, illite-vermiculite, arsenopyrite, marcasite, pyrite, pyrrhotite and chalcopyrite. Some other minerals, such as scorodite $\left(\mathrm{FeAsO} \mathrm{O}_{4} 2 \mathrm{H}_{2} \mathrm{O}\right)$ and natrojarosite, resulting from the 
Fiúza, A., et al, 2021. Quantitative Risk Assessment of Environmental Hazards Generated by a Tailing Embankment..., 132 (4): $465-486$

\begin{tabular}{|cccccccccc}
\hline & \multicolumn{10}{c}{ Concentrations (\%) } \\
\hline & $\mathrm{Mn}$ & $\mathrm{Fe}$ & $\mathrm{Cu}$ & $\mathrm{Zn}$ & $\mathrm{As}$ & $\mathrm{Sn}$ & $\mathrm{Sb}$ & $\mathrm{W}$ & $\mathrm{Hg}$ \\
\hline Average & 0.15 & 27.84 & 0.60 & 1.41 & 15.50 & 0.09 & 0.01 & 0.39 & 0.05 \\
Standard Deviation & 0.080 & 1.705 & 0.199 & 0.387 & 2.979 & 0.016 & 0.001 & 0.127 & 0.008 \\
Median & 0.15 & 27.42 & 0.55 & 1.43 & 14.97 & 0.09 & 0.01 & 0.40 & 0.05 \\
Maximum & 0.27 & 31.28 & 1.15 & 2.78 & 22.29 & 0.12 & 0.01 & 0.59 & 0.07 \\
\hline Minimum & 0.01 & 24.29 & 0.20 & 0.72 & 10.19 & 0.06 & 0.00 & 0.06 & 0.03 \\
\hline
\end{tabular}

Table 2. Average concentrations of the main elements (80 samples).

Tabla 2. Concentraciones medias de los elementos principales (80 muestras).

oxidation of arsenopyrite, were also present in smaIler quantities and enriched in $\mathrm{As}, \mathrm{Cu}, \mathrm{Mn}, \mathrm{Pb}$ and $\mathrm{Zn}$.

The typical reaction of the oxidation of arsenopyrite in the supergene environment is the following (Dove and Rimstidt (1985),

It is a chemical reaction that produces the acid that

$$
\mathrm{FeAsS}+14 \mathrm{Fe}^{3+}+10 \mathrm{H}_{2} \mathrm{O} \rightarrow 14 \mathrm{Fe}^{2+}+\mathrm{SO}_{4}^{2-}+\mathrm{FeAsO}_{4} \cdot 2 \mathrm{H}_{2} \mathrm{O}+16 \mathrm{H}^{+}
$$

infiltrates through the tailings embankment, outcropping on its base on the left bank of the Zêzere River where the low pH (2.6 to 3.8) of the runoff waters and the abundance of iron precipitates is evident, as a result of the oxidation of the sulphides.

\section{Simulation of Natural Leaching}

Some of the samples collected were used to perform natural leaching tests, performed in stirred beakers with distilled water for a maximum period of $24 \mathrm{~h}$. The tests were interrupted to collect samples of the liquid phase after 1, 3, 12 and 24 hours. In these samples, $\mathrm{pH}$, dissolved oxygen, salinity, total dissolved solids, conductivity and temperature were measured. The solid residues were analysed and the chemical composition was compared with the initial one. The tests followed the DIN38414-S4 standard. The main conclusions were:

a. all the samples showed an acidic $\mathrm{pH}$ ranging from 2.0 to 3.8 , revealing oxidation of sulphides with the release of hydronic cation;

b. the superficial samples produce a greater amount of acid (lower pH between 2.0 and 2.3) than the deeper samples, with values of between 3.2 and 3.8;

c. for the superficial samples the $\mathrm{pH}$ remains approximately constant whilst for the 'deeper' samples there is a time delay in the production of acid, decaying on average from 3.8 to 3.2 .

Two methods were used for predicting the acid generation: the modified acid-base accounting method (Coastech, 1989) and the net acid generation (NAG) procedure (Coastech, 1989). All the tests, with all the chosen samples, evidenced an extremely high capacity for acid generation.

\section{Climate, hydrological cycle and model of water circu- lation and balance}

The meteorological data obtained during the last 30 years from a nearby locality, were used to characterise the mean values of the daily maximum temperatures, daily minimum, daily average and monthly

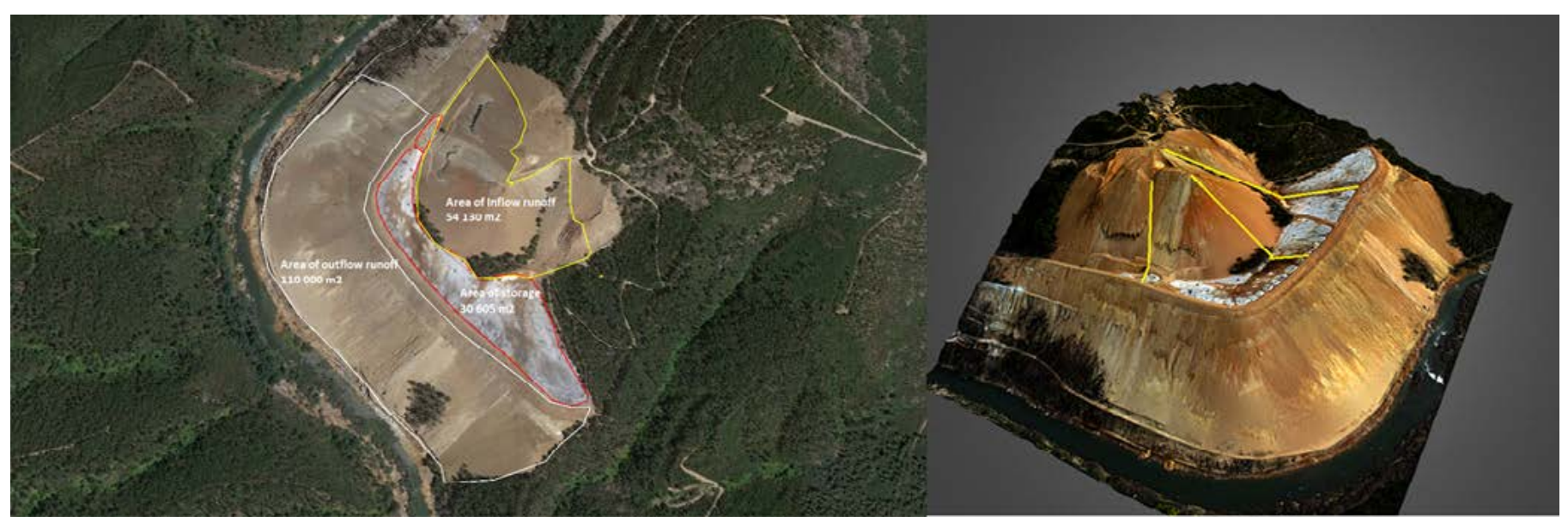

Figure 5. Catchment areas and main water streams.

Figura 5. Áreas de captación y principales corrientes de agua. 
minimums, as well as the wind velocity and precipitation (Meteoblue Data Source). The histogram of the average monthly precipitations identifies three distinct rainfall periods: i) a dry period (includes June, July, August and September) coincident with the highest temperatures; (ii) a rainy season (October, November, December and January); (iii) a transitional period (February, March, April and May). The annual mean values published for precipitation $(1,300 \mathrm{~mm})$, superficial runoff $(400 \mathrm{~mm}$, European Environmental Agency) and evapotranspiration $(900 \mathrm{~mm}$ ) (Lúcio do Rosário, 2004) were selected to implement a water balance. Figure 5 shows on the left the areas of the sludge storage, as well as the areas for inflow and outflow runoff, where the values were determined. In the tailings embankment it is possible to distinguish three water streams, represented by yellow lines (Fig. 5 , right) that discharge to the deposit.

Based on this information, it is possible to develop a water balance for the study area and the conceptual model is presented in Figure 6.

The storage area receives the direct precipitation and the runoff from the higher levels that drain to the site as input. It has two outputs: the water lost by evapotranspiration and by infiltration (Table 3).

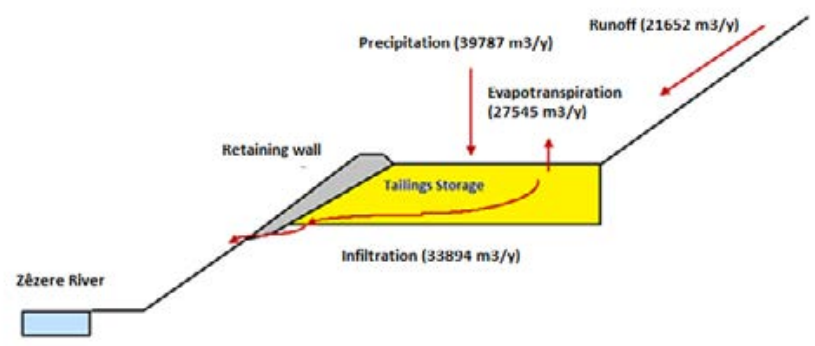

Figure 6. Hydrological balance of the conceptual model. Figura 6. Modelo conceptual del balance hidrológico.

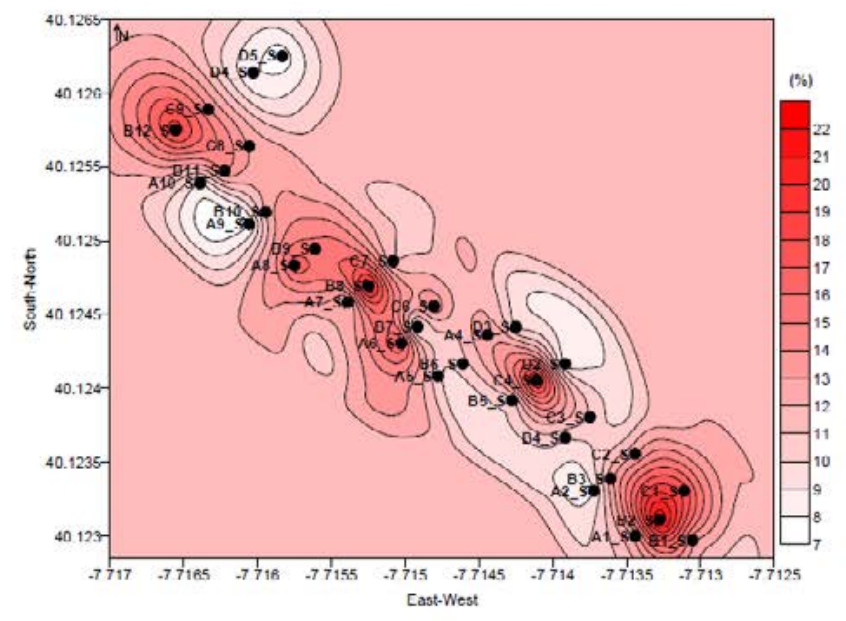

a)

\begin{tabular}{|c|c|c|c|}
\hline & Average value (mm) & Area $\left(\mathrm{m}^{2}\right)$ & Flowrate $\left(\mathrm{m}^{3} / \mathrm{y}\right)$ \\
\hline \multicolumn{4}{|l|}{ Input } \\
\hline Inflow runoff & 400 & 54130 & 21652 \\
\hline Rainfall & 1300 & 30605 & 39787 \\
\hline Total & & & 61439 \\
\hline \multicolumn{4}{|l|}{ Output } \\
\hline Evaporation & 900 & 30605 & 27545 \\
\hline $\begin{array}{l}\text { Infiltration } \\
\text { Total }\end{array}$ & & & $\begin{array}{l}33894 \\
61439\end{array}$ \\
\hline
\end{tabular}

Table 3. Water balance for the storage embankment

Tabla 3. Balance de agua para el almacenamiento de relaves

From this information, it is possible to estimate an average flow of infiltrated water, which will be in contact with the tailings of $33,894 \mathrm{~m}^{3} / y e a r$, corresponding to an average approximate flow of $92.7 \mathrm{~m}^{3} / \mathrm{d}$. As we are considering a steady-state situation, without variation in the volume of water stored within the embankment, the same flow will be drained to the riverbank after some residence time. This value was used in the environmental dispersion models for quantifying the risk.

The total volume of sludge in the embankment is $730,000 \mathrm{~m}^{3}$ with a porosity of $50 \%$. If we still consider that the average depth of the unsaturated zone is $4 \mathrm{~m}$, according to the drills (Gama, 2002) the total volume of stored water is $320,000 \mathrm{~m}^{3}$ with an average residence time in the embankment of 10.7 years.

\section{Quantification of hazardous elements existing in the embankment}

The distribution of heavy metals within the embankment is not homogeneous. Under the project Remine,

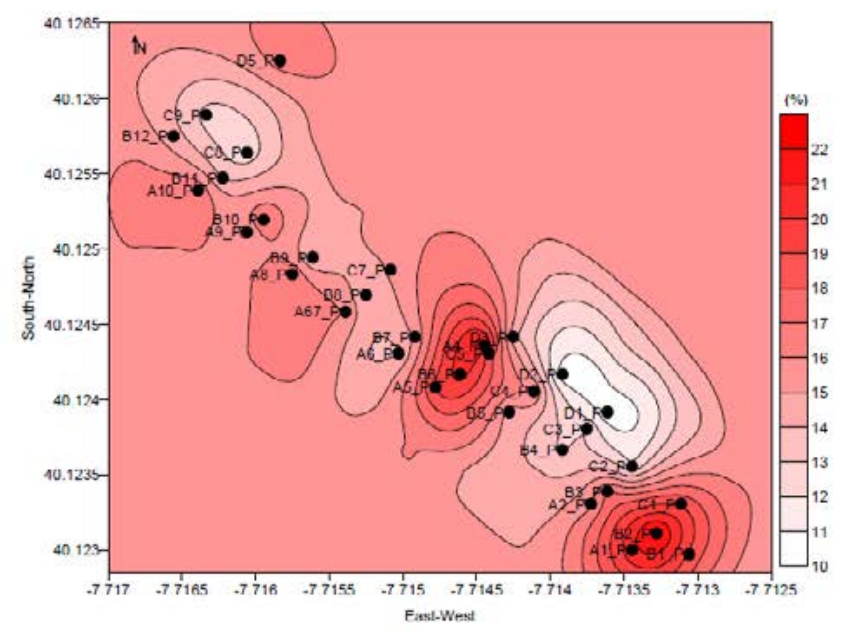

b)

Figure 7. Space distribution of arsenic concentrations for superficial (a) and 'deep' samples (b).

Figura 7. Distribución espacial de las concentraciones en arsénico para muestras superficiales (a) y "profundas"(b). 
Albuquerque et al., (2017) verified by "Cluster analysis" that As was associated with $\mathrm{Sn}$, whilst $\mathrm{Cu}, \mathrm{Zn}$ and $\mathrm{Cd}$ were associated with each other.

The chemical grades were processed by geostatistics to estimate, predict and map their spatial distribution. The geographic coordinates were used for geo-referenciation of the grades, using the software Surfer ${ }^{\circledR}$ (Golden Software Inc., 2017). The final output was a set of spatial distribution maps, elaborated for each main element analysed with high abnormal concentrations.

Experimental variograms were created through the spatial data structure analysis, characterising the degree of spatial dependence between samples (Figueiredo, 2019). The best fit model of the experimental variogram was the spherical model (Figueiredo, 2019). Kriging was chosen to perform the netting interpolation of the georeferenced information, thus allowing a spatial inference of quantities in unobserved locations and quantifying the uncertainty associated with the estimator. The space distribution of arsenic for superficial and for deep samples are shown in Figure 7 (Gois, 2018).

In the assessment of the total quantities of the different heavy metals existing in the sludge embankment, the primary data used for calculation was the estimated volume of material existing in the dam $(730,000$ $\left.\mathrm{m}^{3}\right)$, the average concentrations of the 'deep' samples and the average wet density $\left(2.23 \mathrm{t} / \mathrm{m}^{3}\right)$. The assessed values are shown in table 4.

\begin{tabular}{lccccccccc} 
& Mn & \multicolumn{1}{c}{ Fo } & \multicolumn{1}{c}{ Cu } & \multicolumn{1}{c}{ Zn } & \multicolumn{1}{c}{ As } & Sn & Sb & W & Hg \\
\hline Average Grade (\%) & 0.15 & 27.84 & 0.6 & 1.41 & 15.5 & 0.09 & 0.01 & 0.39 & 0.05 \\
\hline Stored Quantity (t) & 2442 & 453207 & 9767 & 22953 & 252325 & 1405 & 163 & 6349 & 814
\end{tabular}

Table 4. Estimation of the quantities of the different heavy metals and metalloids stored in the sludge embankment.

Tabla 4. Estimación de las cantidades de los diferentes metales y metaloides pesados almacenados en la presa de relaves.

\section{Oxidation of sulphides and formation of acid mine drainage}

The acid-producing tests evidenced a high capacity for acid generation that was confirmed in the field. For this purpose, two campaigns were performed to collect leachate samples at the base of the slope, in March and June 2018. The values obtained are in Table 5.

\begin{tabular}{lcccccc}
$\begin{array}{c}\text { Corcentratiurs in mg1 } \\
\text { (average values, 3 samples) }\end{array}$ & Al & As & Cd & Cu & Mn & Zn \\
\hline March sampling & 150 & 99 & 0.44 & 44 & 138 & 59 \\
\hline June sampling & 113 & 6.3 & 0.45 & 37 & 252 & 55 \\
\hline
\end{tabular}

Table 5. Concentration in heavy metals and metalloids of the leachates produced in the tailings embankment.

Tabla 5. Concentración en metales pesados y metaloides en los lixiviados producidos en los relaves.

The concentrations in As show a high discrepancy between the two measurements. In previous studies carried out by Candeias ${ }^{\mathrm{a}}$ (2014), which made several collections of leachates, the mean values obtained were as follows: $\mathrm{pH}(2.6-3.8)$, electrical conductivity $(679-733 \mathrm{mV})$, high Fe concentrations $\left(12-172 \mathrm{mg} \mathrm{l}^{-1}\right)$ with high concentrations in As $\left(561-21,000 \mathrm{mg} \mathrm{l}^{-1}\right), \mathrm{Cd}$ $\left(86-1179 \mu \mathrm{g} \mathrm{l}^{-1}\right)$ and $\mathrm{Cu}\left(822-99,696 \mu \mathrm{g} \mathrm{I}^{-1}\right)$. Whilst the $\mathrm{Cd}$ concentrations agreed with our determinations, the values for As and $\mathrm{Cu}$ are different. The disparity probably results from the use of different sampling sites, and the high seasonal variability, typical of this type of sulphide waste storage should also be taken into account.

As a consequence, it was extremely difficult to select an average value for the arsenic concentration in the leachates, given its high spatial variability and seasonal variation. A perspective of parsimony was adopted, so that the minimum average value measured in the samples was assumed as the average value $(6,300 \mu \mathrm{g} \mathrm{l}-1)$ which is much lower than the maximum observed in previous studies. Considering the existence of a volume of leachate within the storage of sludge to be $320,000 \mathrm{~m}^{3}$, the amount of arsenic leached (dissolved) is $2,016 \mathrm{~kg}$.

\section{Considerations on structural stability and the risk of rupture of the tailings dam}

The data obtained from the surveys has allowed us to construct a model for the groundwater drainage system (Fig. 8).

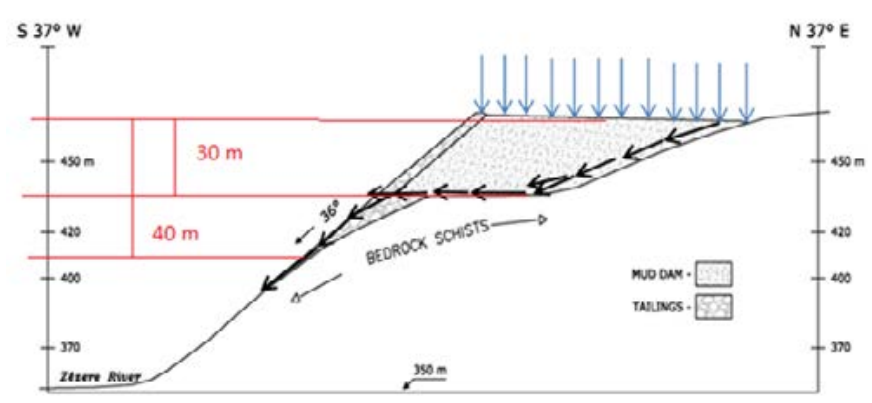

Figure 8. Conceptual model for the flow of the infiltrated water based on the results of drilling (Ineti, 2006)

Figura 8. Modelo conceptual para el flujo del agua infiltrada basada en resultados de sondeos (Ineti, 2006)

In this model there is a resurgence of water on the surface of the embankment slope, at a distance from the crest of about 40 meters. This resurgence may be responsible for the erosive process visible in the slope, resulting from the flow of leachates in the tailings/bedrock interface. In 2010, Silva (2010) made a geophysical survey of the crest and the slopes of the dam, using ground-penetrating radar (GPR). Six profiles were produced on the crest of the dam and three on the slope confirming this model and interpretation.

Although several different dam failures may occur (overtopping, piping, foundation, excessive water level, seismic events) rupture due to the erosion of the con- 
tainment wall of the embankment could be considered the most probable. The water that arrives at the dam (precipitation and superficial runoff) flows through the storage of sludge that is supported at the bottom by the bedrock. As the hydraulic conductivity of the unfractured bedrock is very low (from $10^{-9}$ to $10^{-12} \mathrm{~m} \mathrm{~s}^{-1}$ for this type of rock formation), acting as an impervious layer, the infiltrated water flows through the exposed slope progressively eroding the base of the containment wall.

The infiltrated waters first flow through a sub-vertical descending movement that continues by a slightly sub-horizontal inclined movement in the area of contact with the pre-existing rock formations (bedrock), leading to piping with water resurgence on the exposed slope, in the area where the bedrock supports the wall. The base of the containment wall is progressively eroded and can lead to its collapse, as evidenced by the visible gullies at the site. This erosive action is continuous, originating the removal and continuous transport of the materials that constitute the support wall (Fig. 9).

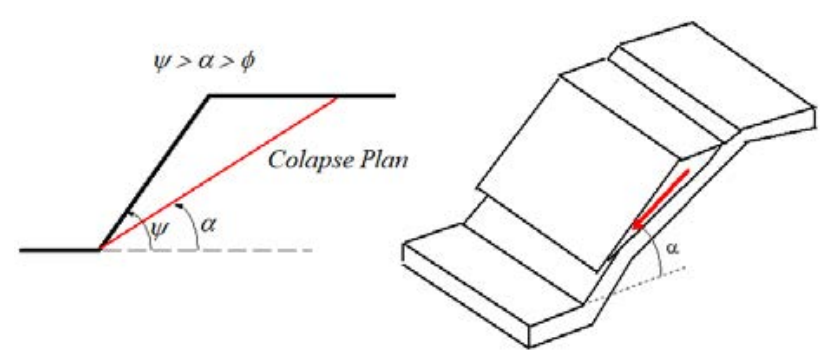

Figure 9. Collapse of the embankment wall.

Figura 9. Colapse del dique de la presa.

This type of failure is the most probable to occur and will lead to a partial collapse of the dyke retaining wall, which will fall into the valley, destroying the crest of the dam in the neighbouring upper area, thus allowing the flow of the stored sludge. Naturally, this type of accident is most likely with the action of heavy rain.

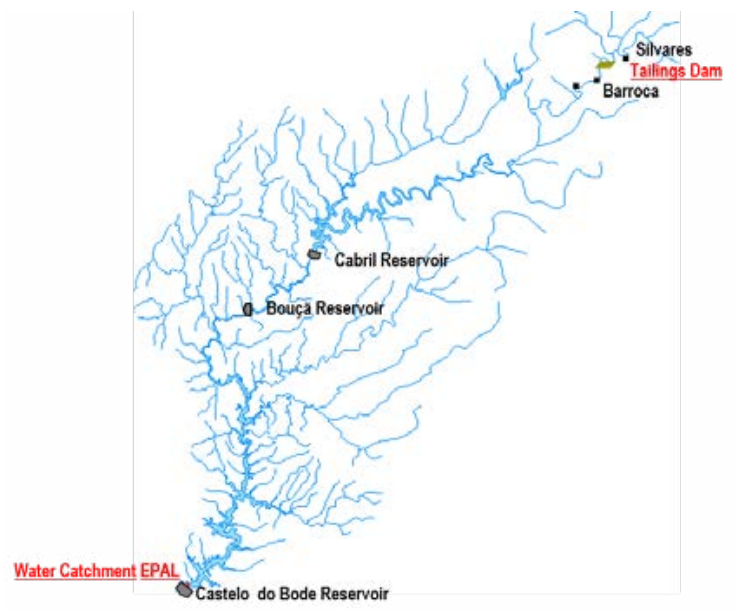

Figure 10. Drainage basin of the Zêzere River (Ferreira R., 2012). Figura 10. Cuenca de drenaje del río Zézere (Ferreira R., 2012).
Figure 10 shows the drainage basin of the Zêzere river, with the locations of the nearest three water dam reservoirs as well as the tailings disposal ('Escombreira do Rio'). The nearest water reservoir, Barragem do Cabril has a capacity of $720 \mathrm{hm}^{3}$.

The most probable location for this rupture is the area affected by the predominant runoff water line where the decrease of the height in the crest of the dam and the sharp erosion of the slope is already visible (Fig. 11).

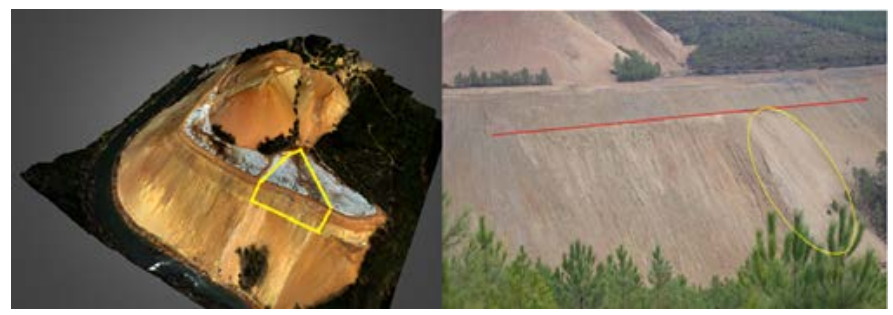

Figure 11. Most probable area of rupture due to erosion of the embankment wall and erosion zones below the support wall.

Figura 11. Zona más probable de colapse por erosión del muro de la presa y zonas de erosión debajo del muro de soporte.

If such a failure occurs, with the partial release of the material stored in the zone shown in Figure 11, it will lead to the release, in a short space of time, of 200,000 $\mathrm{m}^{3}$ of waste, equivalent to 490,600 tonnes, with a total arsenic content of 73,590 tonnes. This release would occur under simultaneous associated erosive action at the dam crest and in the resurgence zone in the slope. Simultaneously, about $91,400 \mathrm{~m}^{3}$ of leachates would be released with an average concentration of $6,300 \mathrm{~g} \mathrm{l}^{-1}$ which corresponds to a release of $575.8 \mathrm{~kg}$ of dissolved arsenic.

\section{Legislation, toxicology and selection of hazardous elements}

In Portugal, the last inventory of closed mining waste facilities, made publicly available in 2013 , complying with the provisions of Directive 2006/21/EC and following Decree-Law No. 10/2010 and 31/2013, considers that the tailings of Cabeço do Pião do not exist in an abandoned mine. It also considers that the tailings are already safely contained and therefore do not originate leachates, acid drainage and dust that could affect the normal usage of the soil, with only some safety problems (presumably related to the stability of the side-hill impoundment). On the other hand, if the tailings are considered as waste, the European Commission Decision 2014/955/EU, referred as the Union List of Hazardous Waste and the Commission Regulation (EU) No 1357/2014, considers the sludge as carcinogenic with the Hazard Class HP7 (Regulation (UE) N.O 1357/2014). The following toxicological effects should then be considered: acute toxicity 3 (inhalation) (H331), acute toxicity 3 (oral) (H301), aquatic acute toxicity $1(\mathrm{H} 400)$ and chronic aquatic toxicity 1 
(H410) (Regulation UE N.o 1357/2014). If the tailings are considered as contaminated soil, then the legisIation applicable in Portugal is the Environmental Protection Act of the Ontario State (Canada), and the elements $\mathrm{Sb}, \mathrm{As}, \mathrm{Cu}$ and $\mathrm{Zn}$ are above the permitted concentrations.

To select the toxic and the carcinogenic elements the database IRIS (Integrated Risk Information System), made for EPA by the National Library of Medicine, in the United States (US EPA, 1997, 2013, 2014 ) was used. The conclusions are displayed in Table 6.

\begin{tabular}{|l|lc|cc|}
\cline { 2 - 5 } \multicolumn{2}{c|}{} & Ingestion & Inhalation & Dermal contact \\
\hline \multirow{5}{*}{ Carcinogenic } & Arsenic & $\mathrm{x}$ & $\mathrm{x}$ & $\mathrm{x}$ \\
\cline { 2 - 5 } & Cadmium & & $\mathrm{x}$ & \\
\hline \multirow{5}{*}{ Toxic } & Antimony (metal) & $\mathrm{x}$ & $\mathrm{x}$ & $\mathrm{x}$ \\
\cline { 2 - 5 } & Arseric, inorganic & $\mathrm{x}$ & $\mathrm{x}$ & $\mathrm{x}$ \\
& Cadmium (dietary) & & $\mathrm{x}$ & \\
\cline { 2 - 5 } & Cadmium (water) & & $\mathrm{x}$ & $\mathrm{x}$ \\
\cline { 2 - 5 } & Lead and Compounds & $\mathrm{x}$ & & $\mathrm{x}$ \\
\hline & Mercury, Inorganic salts & $\mathrm{x}$ & & $\mathrm{x}$ \\
\cline { 2 - 5 } & Tin & $\mathrm{x}$ & & $\mathrm{x}$ \\
\cline { 2 - 5 } & Zinc (Metal) & $\mathrm{x}$ & & \multicolumn{2}{c}{} \\
\hline
\end{tabular}

Table 6. Carcinogenic and toxic heavy metals and metalloids in the tailings.

Tabla 6. Metales pesados y metaloides cancerígenos y toxicos en los relaves.

As usually happens in toxicological environmental impact studies out of all these elements, just one or two elements are responsible for more than $99 \%$ of the potential toxic load. For this reason, only arsenic was considered in the environmental impact assessment.

\section{Toxicology of arsenic}

Arsenic is present in all living organisms and the total quantity in the human body varies between 3 and 4 $\mathrm{mg}$ increasing with age (U.S. EPA, 2014). Except for hair, nails and teeth the analyses revealed that most of the human body tissues contain less than $0.3 \mathrm{mg} /$ kg (Samanta et al., 2014). In the United States, the median arsenic content of 1,000 human hair samples was $0.51 \mathrm{mg} / \mathrm{kg}$, and the medians were 0.62 and 0.37 $\mathrm{mg} / \mathrm{kg}$ respectively for males and females (Fowler et. al, 2015). The nails of a patient with acute polyneuropathy due to arsenic poisoning contained 20 to 130 $\mathrm{mg} / \mathrm{kg}$, whilst the normal nail concentration was 0.43 $-1.08 \mathrm{mg} / \mathrm{kg}$ (WHO, 2001).

Human exposure to arsenic is mainly due to food and water intake (Bundschuh, 2007). From these the diet is usually the main contributor to the daily dose ingested. The arsenic concentration of the urine varies from 0.1 to $1.0 \mathrm{mg} \mathrm{l}^{-1}$ (WHO, 2001). Large daily variations are depending on the food consumed throughout the day, the highest concentrations being found with the consumption of shellfish (WHO, 2001). When arsenic is ingested, the amount excreted increases for several days and then declines, until a normal value is reached (U.S. EPA, 2001). Drinking water represents the greatest danger since the species present in the groundwater are predominantly inorganic forms, and are the most toxic. The actual legislation for maximum concentration in drinking water is $10 \mu \mathrm{g} \mathrm{I}^{-1}$, following the WHO recommendations.

Chronic exposure to arsenic in ingested water is related to an increased risk of cancer in the skin, lungs, bladder and kidneys, as well as skin alterations such as pigmentation and thickness alterations (hyperkeratosis). It is estimated that at least $\mathbf{5 0 0}$ million people in the entire planet are consuming arsenic above the limits recommended by the World Health Organization $\left(10 \mu \mathrm{g} \mathrm{I}^{-1}\right)$.

\section{Characterization and quantification of the reference state}

\section{Surface water}

The Zêzere River has for subsidiary, a water stream called "S. Francisco stream" or "Casinhas stream", which receives eventual leachates produced by the main tailing disposal of the Panasqueira Mine, located in Barroca Grande (Fig. 12). The concentrations of arsenic in water, as well as many other cations and anions, also including the typical parameters of water quality, were surveyed by Candeias ${ }^{\mathrm{a}}$ et al., (2014). The author collected samples from runoff water, from the S. Francisco stream and the Zêzere river.

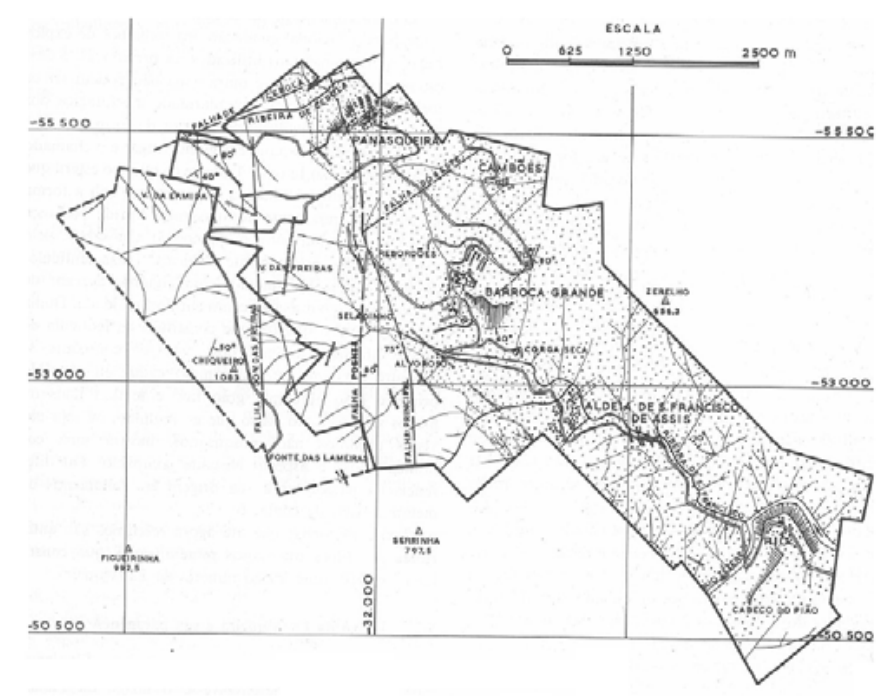

Figure 12. Panasqueira Area with water streams (Cláudio dos Reis). Figura 12. Área da Penasqueira con cursos de agua (Cláudio dos Reis).

Analysis of water samples collected in the S. Francisco stream, in the Zêzere river before and after the tailings embankment drew the following conclusions:

- The runoff waters of the Cabeço do Pião embankment have the most acidic $\mathrm{pH}$ (2.9 to 3.2$)$ 
and the highest values in concentrations in $\mathrm{Al}$ (99 to $161 \mathrm{mg} \mathrm{l}^{-1}$ ), As (146 to $\left.2140 \mu \mathrm{g} \mathrm{l}^{-1}\right), \mathrm{Cd}(226$ to $\left.464 \mu \mathrm{g} \mathrm{I}^{-1}\right), \mathrm{Cu}\left(20.2\right.$ to $\left.54.3 \mathrm{mg} \mathrm{l}^{-1}\right), \mathrm{Mn}(22.3$ to $\left.92.6 \mathrm{mg}^{-1}\right)$ and $\mathrm{Zn}$ (21.9 to $\left.49.2 \mathrm{mg} \mathrm{l}^{-1}\right)$. They also show high concentrations in suspended solids;

- The concentrations in arsenic in runoff waters originated at the embankment are very high (frequently over $2,000 \mu \mathrm{g} \mathrm{I}^{-1}$ ), whilst they are slightly above the drinkability threshold in the $S$. Francisco stream $\left(13 \mu \mathrm{g} \mathrm{l}^{-1}\right)$ and much lower in the river background $\left(4 \mu \mathrm{g}^{-1}\right)$.

- The low concentrations of arsenic in the river water can be explained by the fact that this element is sorbed by the iron oxides and hydroxides, precipitating at the bottom of the river and integrating the sediments.

- During the rainy season, the $\mathrm{pH}$ increases $(3.9$ to 5.7) and the secondary minerals dissolve releasing arsenic. The dissolution and precipitation of these secondary minerals are strongly affected by the cycles of rainfall and drying (for example, Fe may vary between $<30$ to $130 \mu \mathrm{g}$ $\left.I^{-1}\right)$.

- Sediments evidence high concentrations in As, with values between 333 and $1489 \mathrm{mg} / \mathrm{kg}$, revealing higher concentrations of the smaller particles. This fact supports the sorption of As by precipitates of iron oxide-hydroxides.

\section{Groundwater}

The values obtained in the S. Francisco village, which is potentially affected by the current tailings disposal at the Panasqueira mine but not by the Cabeço do Pião embankment, evidenced concentrations below the drinkable threshold $\left(10 \mu \mathrm{g} \mathrm{I}^{-1}\right)$.

\section{Flora}

The same author (Candeias ${ }^{c}$ et al., 2014) studied the concentrations of heavy and metalloid metals (As, Cd, $\mathrm{Cu}$ and $\mathrm{Mn}$ ) in potatoes and cabbage leaves. The different parts of the plant were analysed for each of these vegetables, from the root to the leaves. The analysis of the results shows that the concentration of As could vary between 0.8 and $14.4 \mathrm{mg} \mathrm{kg}^{-1}$. These values were compared with the limit established by the $\mathrm{FAO} /$ WHO $(0.1 \mathrm{mg} / \mathrm{kg})$.

\section{EIA - Alternative environmental scenarios}

Two alternative scenarios were considered:

The first scenario assesses the environmental impact considering the present situation, with a continuous release of an environmental charge by the tailing embankment. In a modelling perspective it corresponds to a steady-state with several sources with continuous-release, constant in time, constituting step disturbances;
- The second scenario considers the occurrence of a failure in the tailings dam, with partial collapse and release of a large amount of 'sludge' and leachates in a short time interval. Mathematically, it can be represented by an instantaneous release (impulse) or by a rectangular pulse.

For the first environmental scenario the following hydrological data, collected from Ferreira et al., (2012) were considered:

- Width of the riverbed in Cabeço do Pião variable between 30 and $56 \mathrm{~m}$; At the base of the embankment the average value is $30 \mathrm{~m}$.

- Flow rate $(\mathrm{m} / \mathrm{s})-1,05$.

- Average depth of the river at location - $1.2 \mathrm{~m}$.

- Estimated flow rate on an empty cross-section basis $-19 \mathrm{~m}^{3} / \mathrm{s}$.

For the second scenario the following assumptions were considered:

- Release of $200,000 \mathrm{~m}^{3}$ of waste in a short time interval under the action of a failure originated by partial collapse of the supporting wall, followed by overtopping in a situation of heavy rainfall.

- The leachates that occupy the voids in the saturated zone of the storage would be released simultaneously with the tailings. From200,000 $\mathrm{m}^{3}$ of tailings, a volume of leachates of about $90,000 \mathrm{~m}^{3}$ is estimated, with an average concentration in As of $6,300\left(\mu \mathrm{g} \mathrm{I}^{-1}\right)$, which corresponds to a sudden release to the river of $567 \mathrm{~kg}$ of dissolved arsenic.

- Considering an intensity of precipitation in the hydrographic basin of $7 \mathrm{~mm} / \mathrm{h}$ and considering the area of the hydrographic basin as 1,611.7 $\mathrm{km}^{2}$, the maximum flow estimated is $2,507 \mathrm{~m}^{3} / \mathrm{s}$.

- Nevertheless, in this study we will adopt a peak flow rate of $1,929 \mathrm{~m}^{3} / \mathrm{s}$, a value adopted by Ferreira (2012), despite the difference in assumptions.

- We can use this flow to "estimate" the average linear velocity of the river by assuming an increase in the width of the river of $20 \%$ and an increase in height of $40 \%$. We would have an

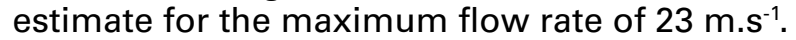

- This maximum speed would only occur during a short time in the collapse area of the dam.

- Under these conditions, the average velocity of the river, between the Cabeço do Pião and the reservoir of the Cabril Dam, is assumed to be about $50 \%$ higher than the average velocity under normal conditions. As this corresponds to an increase of $68 \%$ in the average cross-section of the river, the corresponding rise in the average flow rate is $252 \%$. Thus, for simulation purposes, an average velocity of the river along this route of $1.5 \mathrm{~m} \mathrm{~s}^{-1}$ is assumed.

Alternative 1 - present steady-state situation. Convective transport by the river in steady-state conditions 
The following mechanisms of transport and fate were considered for arsenic: transport by the river (with advection, sorption into sediments and bio-concentration in fish), atmospheric transport by incorporation into dust, dust deposition and concentration in the soil and flora.

A mathematical model of transport by the river with advection and degradation was used:

$\frac{\partial C}{\partial t}=-u \frac{\partial C}{\partial x}-\lambda C$

or in steady-state conditions

$u \frac{d C}{d x}+\lambda C=0$

where $C$ represents the concentration in As that depends on location in the river ( $x$ - distance to the origin - point of entrance of the leachates), $\lambda$ is a pseudo-first-order kinetic constant. The kinetic constant incorporates sorption in suspended particles, the deposition of sedimentation of particle aggregates, the degradation processes (sum of hydrolysis, photolysis, biodegradation and others), and the eventual volatilisation. Protolysis does not occur in this case.

Initially, the As concentration in the Zêzere River is calculated at the inlet site of the leachates generated at the tailings embankment. Conceptually the river, with a flow rate of $17 \mathrm{~m}^{3} / \mathrm{s}$ and with an average concentration in As of $4 \mathrm{\mu g} \mathrm{I}^{-1}$ is initially mixed with the water from the $\mathrm{S}$. Francisco stream which has an average concentration in As of $13 \mu \mathrm{g} \mathrm{l}^{-1}$ and where the flow is assumed to be $2 \mathrm{~m}^{3} / \mathrm{s}$. This watercourse then receives the flow of leachates from the sludge embankment, about $92.7 \mathrm{~m}^{3} / \mathrm{d}$ (i.e. $0.001 \mathrm{~m}^{3} / \mathrm{s}$ ) with a concentration of $6.3 \mathrm{mg} \mathrm{l}^{-1}$. Assuming immediate mixing effects, the Zêzere River would have a flow rate at the inlet point of $19 \mathrm{~m} 3 / \mathrm{s}$ with an average arsenic concentration of

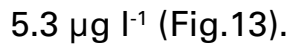

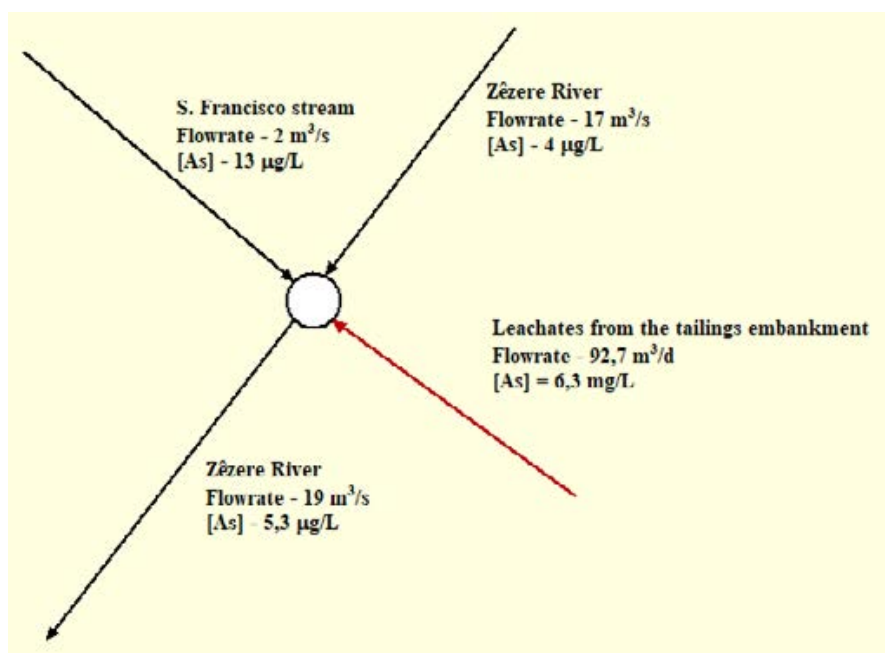

Figure 13. Average flowrates and As water concentrations.

Figura 13. Caudales medios y concentraciones de As en el agua.
In the application of the model, it was considered that there was no transfer to the atmosphere and that there was no biodegradation, the with sorption into the suspended sediments consisting of a high percentage of iron oxide-hydroxides, the only degradation mechanism. The sorbed fraction in the sediments was $70 \%$, with $30 \%$ the fraction of As dissolved in water was also recognised. The values for the main parameters involved in the risk assessment model are shown in Table 7.

\begin{tabular}{ll} 
River flowate $\left[\mathrm{m}^{3} / \mathrm{s}\right]$ & 19 \\
\hline Velocity of the river $[\mathrm{m} / \mathrm{s}]$ & 1.05 \\
\hline Average depth $[\mathrm{m}]$ & 1.2 \\
\hline Wind velocity $10 \mathrm{~cm}$ above water surface $[\mathrm{m} / \mathrm{s}]$ & 2 \\
\hline Half-life by degradation, days & 1000000 \\
\hline Suspended solids $\left[\mathrm{g} / \mathrm{m}^{3}\right]$ & 50 \\
\hline Sedimentation rate $[\mathrm{mm} /$ year] & 2 \\
\hline Density of sediments $\left(\mathrm{kg} / \mathrm{m}^{3}\right)$ & 1300 \\
\hline Sediment porosity & 0.2 \\
\hline Organic carbon partition coefficient for As, $\mathrm{ml} / \mathrm{g}$ & 0 \\
\hline Fraction of organic matter in sediments & $0 \%$ \\
\hline Molecular weight of arsenic & 74.92 \\
\hline Adimensional Henry constant & $1.00 \mathrm{E}-07$ \\
\hline Bio Concentration Factor $(\mathrm{BCF})(1 / \mathrm{kg})$ & 44
\end{tabular}

Table 7. Values for the parameters involved in the risk assessment. Tabla 7. Valores de los parámetros implicados en la evaluación del riesgo.

The application of the model showed that the concentrations of As in the water of the Zêzere river is poorly attenuated, ranging from $5.3 \mu \mathrm{g} \mathrm{I}^{-1}$ to $5.25 \mu \mathrm{g}$ $\mathrm{I}^{-1}$ thirty kilometres away. This concentration profile is due to the fact that the only degradation mechanism is sedimentation. In contrast, the average concentration found in fish is $162 \mu \mathrm{g} / \mathrm{kg}$, because the bio-concentration factor (BCF) for As is high ( $44 \mathrm{~L} / \mathrm{kg})$.

The river also transports the particles released from the embankment. The distance travelled before sedimentation at the bottom of the river bed depends on the average flow velocity. For the average values assumed, adopting a depth for the river of $1.2 \mathrm{~m}$ and a velocity of $1.05 \mathrm{~m} / \mathrm{s}$, it is possible to estimate the distances to which the particles of different sizes are transported, using a settling model (Major, 1978). The particles with the median grain size $(26 \mu \mathrm{m})$ travel 1.5 $\mathrm{km}$ before settling, whilst the finer particles, for example with a size of $5 \mu \mathrm{m}$, would travel $38 \mathrm{~km}$. A particle of size $2 \mu \mathrm{m}$ could travel, ideally without obstacles, $240 \mathrm{~km}$.

Granjeia et al., (2014) measured the concentrations of heavy metals in the sludge and in the sediments in the left bank of the Zêzere River in the Cabeço do Pião area. The relevant mean values obtained for arsenic was $73,649 \mu \mathrm{g} / \mathrm{kg}$. 
The high concentration in As do not derive from particles of arsenopyrite released, but rather from the sorption of dissolved arsenic by sand particles and silts with high iron content. The mechanism has two stages: first, the release at the resurgence zone of leachates, with arsenic and other heavy metals dissolved; next, a slow but continuous sorption of metals, especially arsenic, by iron oxide-hydroxides in the sandy and silty particles. These particles are progressively transported by the Zêzere river creating along its course, and on its shores a continuous range of high concentrated sediments until the water reservoir of Cabril is reached.

\section{Atmospheric dispersion - dust}

Figure 14 represents the mapping of the flux of dust deposition at the beginning of summer in a large area around Cabeço do Pião. The values obtained are considered as representative of the annual average.

By making a brief statistical analysis the following values for depositional flux $\left(\mu \mathrm{g} \mathrm{m}^{-2} \mathrm{~h}^{-1}\right)$ were found (Table 8).

\begin{tabular}{lr} 
Average & 537.7 \\
\hline Standard deviation & 429.9 \\
\hline Median & 482.9 \\
\hline Maximum value & 2400.7 \\
\hline Minimum value & 40.7
\end{tabular}

Table 8. Depositional Flux of dust $\left(\mu \mathrm{g} \mathrm{m}^{-2} \mathrm{~h}^{-1}\right)$

Tabla 8. Flujo de deposición de polvo $\left(\mu \mathrm{g} \mathrm{m}^{-2} h^{-1}\right)$
The average wind velocity in the area is $5.5 \mathrm{~km} / \mathrm{h}$, very rarely exceeding $28 \mathrm{~km} / \mathrm{h}$. Considering the data collected, a concentration of particles in the atmosphere of $30 \mu \mathrm{g} \mathrm{m}^{-3}$ is assumed to be able to assess the environmental risk. Part of the dust originates from the tailing storage, whilst the remaining dust has other origins. In this study is assumed that the dust that affects the most exposed settlements (the villages of Baroque and Dornelas do Zêzere) has $40 \%$ origin from the sludge storage, thus creating an average As concentration of $6.2 \%$ in the dust.

\section{Soil}

Candeias $^{c}$ et al. (2014) published a study on the environmental characterisation of soil in nearby areas of cultivation, but focused exclusively on the village of $S$. Francisco de Assis, which is located between two tailings facilities: southeast of Barroca Grande tailings storage and northwest of Cabeço do Pião. We extracted from the study mentioned above the most relevant mean values. These mean values were obtained from 17 samples of rhizosphere soils and 116 samples of soils from horizon B (Table 9).

The high superficial concentrations (rhizosphere) in arsenic, zinc and copper are especially notable, denoting the transport by wind and water of mineralized particles from the tailings embankments. The B horizon, with samples collected at depths of between 15 and 20 $\mathrm{cm}$, denotes lower concentrations in the same elements, thus evidencing the aforementioned external origin of the high concentrations in the rhizosphere soils.

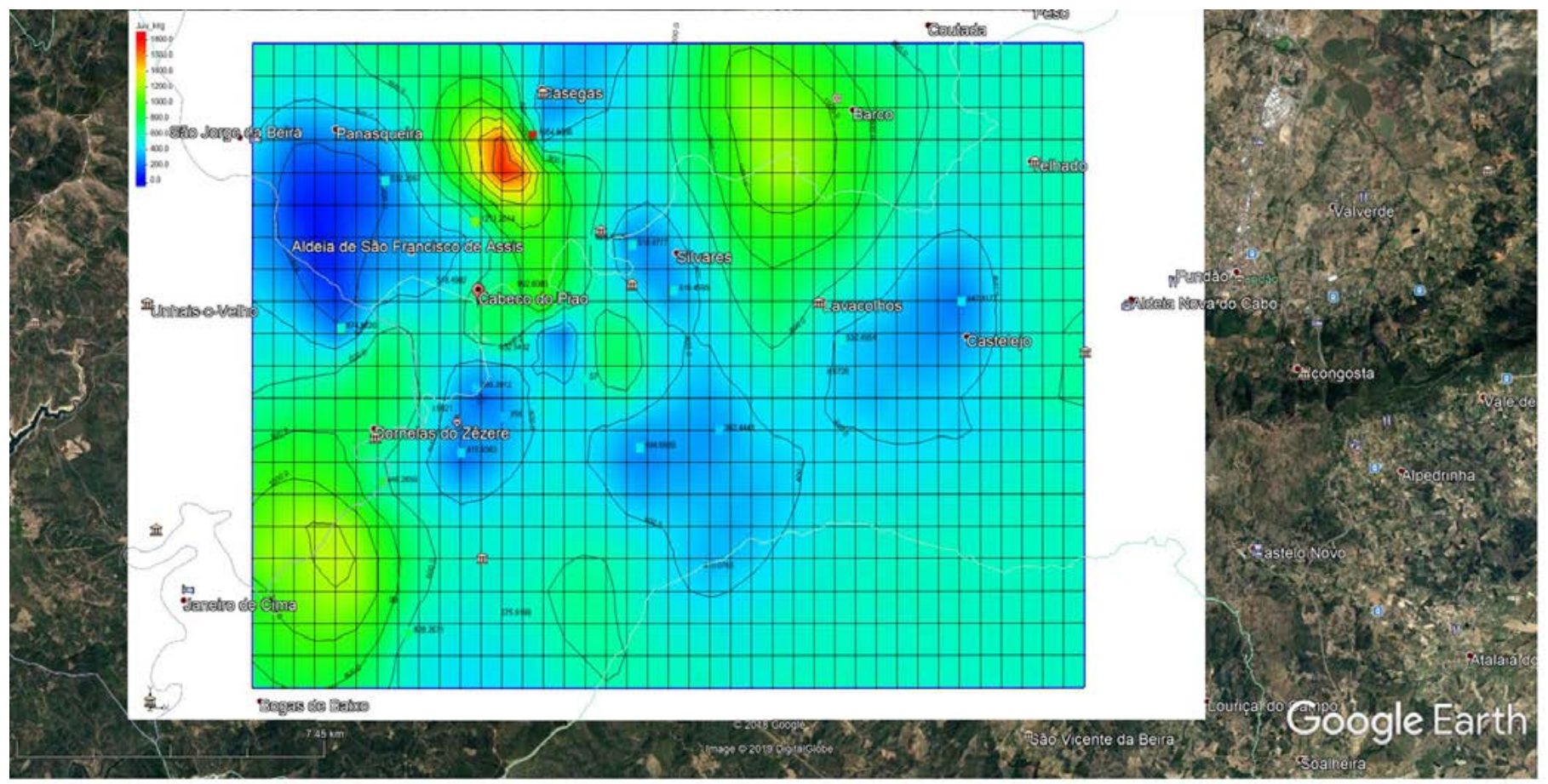

Figure 14. Spatial distribution of the depositional flux of dust.

Figura 14. Distribución espacial del flujo de deposición del polvo. 
Soil in the Rhizosphere Soil Horizon B

\begin{tabular}{llcc} 
& & & \\
$\mathrm{pH}$ & & 6.17 & 4.24 \\
$\mathrm{As}$ & $\mathrm{mg} \mathrm{kg}^{-1}$ & 223.6 & 97.8 \\
$\mathrm{Cr}$ & $\mathrm{mg} \mathrm{kg}^{-1}$ & 37.8 & 34.9 \\
$\mathrm{Cu}$ & $\mathrm{mg} \mathrm{kg}^{-1}$ & 163.7 & 41.7 \\
$\mathrm{Mn}$ & $\mathrm{mg} \mathrm{kg}^{-1}$ & 531.3 & 170 \\
$\mathrm{~Pb}$ & $\mathrm{mg} \mathrm{kg}^{-1}$ & 58.6 & 26.7 \\
$\mathrm{~W}$ & $\mathrm{mg} \mathrm{kg}^{-1}$ & 12.1 & 4.6 \\
$\mathrm{Zn}$ & $\mathrm{mg} \mathrm{kg}^{-1}$ & 323.2 & 85.7 \\
\hline
\end{tabular}

Table 9. Concentrations of some heavy metals and metalloids (mean values) in the soil of the village of S. Francisco de Assis (Candeiasc, 2014).

Tabla 9. Concentraciones de algunos metales pesados y metaloides (valores medios) en el suelo del pueblo de S.Francisco de Assis (Candeiasc, 2014).

\section{Transfer to flora}

The amount of arsenic that accumulates in the tissues of the plants depends on several factors such as the plant type, its edible component and the soil type. In general, when arsenic concentrations in soil and water are high, plant growth and harvesting are reduced, especially for fruit and leaves. Root crops such as radishes, potatoes and onions accumulate arsenic at much higher levels compared to fruit and leaves. MacLean (1981) found the following average concentrations in arsenic in potato crops $9.63 \mathrm{mg} / \mathrm{kg}$ for total arsenic and $0.04 \mathrm{mg} / \mathrm{kg}$ for water-soluble arsenic respectively.

In another study, Codling (2016) studied the concentrations of arsenic in soils contaminated with lead and arsenate, having found for the peeled tubers concentrations varying between 0.44 and $1.44 \mathrm{mg} / \mathrm{kg}$. FinaIly, Haque (2015) studied the arsenic concentration of different varieties of potatoes cultivated in soils with different concentrations in As, from 0.25 to $50 \mathrm{mg} /$ $\mathrm{kg}$. The maximum value of the arsenic concentration, found in potatoes of the 'Courage' variety, is 0.290 $\mathrm{mg} / \mathrm{kg}$ on a dry basis.

The values determined by Candeias ${ }^{c}$ (2014) in potatoes cultivated in the village of S. Francisco de Assis, in agricultural soils heavily contaminated with As, reveal values of $3.5 \mathrm{~m} / \mathrm{kg}$. This value appears excessive compared to the values previously indicated (MacLean, 1981, Haque, 2015, Codling, 2016).

Lanhade (2013) in a systematic study focusing on various types of vegetables and contaminants found arsenic concentrations of between 0.6 and $1.1 \mathrm{mg} / \mathrm{kg}$ in cabbages and between 0.50 and $0.8 \mathrm{mg} / \mathrm{kg}$ for potatoes, with both concentrations being expressed on a dry basis. The mean value measured by Candeias ${ }^{c}$ (2014) for cabbages was $2.9 \mathrm{mg} / \mathrm{kg}$. Again, this value seems excessive compared to published values.

The concentrations measured in tubers (potatoes) and cabbages from agricultural land located in the viIlage of S. Francisco de Assis are too high compared to the values found in the bibliography, even though the average concentration of As in soils of that village largely exceeds soil concentrations referred to in other studies. Similarly, the values estimated throu$\mathrm{gh}$ the partition coefficients recommended by the UK Environment Agency are also much lower. Given this disparity of values, the mean values for the average of the measurements made by Lanhade (2013) $(0.65 \mathrm{mg} /$ $\mathrm{kg}$ for cabbages and $0.85 \mathrm{mg} / \mathrm{kg}$ for potatoes) were adopted. For the exposure scenario, an average consumption of $138 \mathrm{~g} /$ day, i.e., $966 \mathrm{~g} /$ week for both vegetables was considered, a conservative value for the local diet.

\section{Exposure scenario}

Standardised scenarios were used for each exposure pathway. The most relevant values used to evaluate the toxicological impact are shown in Table10.

\begin{tabular}{lc} 
& Adults \\
\hline Average human body weight $(\mathrm{kg})$ & 70 \\
\hline Surface area of the skin $\left(\mathrm{cm}^{2}\right)$ & 18150 \\
\hline ingested water $(\mathrm{l} /$ day $)$ & 1 \\
\hline Breathed air $\left(\mathrm{m}^{3} / \mathrm{h}\right)$ & 0,83 \\
\hline Concentration of dust in the atmosphere $\left(\mathrm{kg} / \mathrm{m}^{3}\right)$ & $3.10^{-6}$ \\
\hline Retention fraction (inhaled air) & $100 \%$ \\
\hline Absorbed fraction (inhaled air) & $100 \%$ \\
\hline Ingested soil $(\mathrm{mg} /$ day) & 100 \\
\hline Potato consumption $(\mathrm{g} /$ day) & 138 \\
\hline Cabbage consumption $(\mathrm{g} /$ day $)$ & 138 \\
\hline Local fish consumption $(\mathrm{g} /$ day $)$ & 70 \\
\hline Fraction of exposed skin area $(\%)$ & $20 \%$ \\
\hline Adhesion of dust to the skin $\left(\mathrm{mg} / \mathrm{cm}^{2}\right)$ & 1 \\
\hline Exposure frequency (days) & 365 \\
\hline Exposure duration (years) & 30
\end{tabular}

Table 10. Values adopted for the exposure scenario.

Tabla 10. Valores adoptados para el escenario de exposición.

\section{Assessment of doses}

Due to its toxicological relevance and high concentrations only one element was considered in this environmental assessment - arsenic. The three exposure pathways, ingestion, inhalation and dermal contact were considered. For ingestion, we considered four possible pathways of penetration in the body: a) water intake from wells; b) soil ingestion (pica effect); this is a very small value, but may strongly contribute to the overall dose; c) ingestion of vegetables (potatoes and cabbages), locally produced, being each one considered separately; d) fish consumption from the river: a small amount was considered, probably corresponding to the reality.

For inhalation, only one mechanism was considered: inhalation of dust. Also, for dermal contact, only one mechanism was considered: contact of dust with the skin. 


\section{Ingestion}

The dose resulting from water ingestion can be calculated using the formula proposed by the Agency for Toxic Substances and Disease Registry (ATSDR, 2005)

$$
D=\frac{C \cdot I R \cdot F E}{P}
$$

where $D$ is the dose $\left(\mathrm{mg} \mathrm{kg}^{-1}\right.$ day $\left.^{-1}\right), C$ is the average concentration of As in water $\left(\mathrm{mg} \mathrm{l}^{-1}\right)$, IR the ingested quantity $\left(\mid \mathrm{d}^{-1}\right), \mathrm{FE}$ the exposure factor (adimensional)) and $P$ the average human body weight $(\mathrm{kg})$.

The ingestion of one litre of water per day was considered, with a concentration of $5.3 \mu \mathrm{g} / \mathrm{L}$. The resulting average dose for an adult is $7.57 .10^{-5} \mathrm{mg} /(\mathrm{kg} . \mathrm{d})$.

Regarding the ingestion of contaminated soil (pica effect) the calculation formula recommended by ATSDR was also considered (ATSDR, 2005)

$$
D=\frac{C \cdot I R \cdot F E \cdot F C}{P}
$$

where $C$ is the average concentration of $A s$ in the soil $(\mathrm{mg} / \mathrm{kg})$, IR is the amount of ingested soil (mg), FE id the exposure frequency, $\mathrm{FC}$ a dimensional concentration factor $\left(10^{-6} \mathrm{~kg} / \mathrm{mg}\right)$ and $P$ the average human body weight $(\mathrm{kg})$.

It was assumed that the soil had an average concentration of $224 \mathrm{mg} / \mathrm{kg}$, which is the mean value in the rhizosphere measured in the village of S. Francisco de Assis, and that the pica effect was converted in the ingestion of $100 \mathrm{mg} / \mathrm{d}(0.1 \mathrm{~g} / \mathrm{d})$ of this soil. The resulting average dose for an adult is $3 \cdot 2 \cdot 10^{-4} \mathrm{mg} /(\mathrm{kg} \mathrm{d})$.

For the ingestion of vegetables, the doses were calculated by the following quantification (ATSDR, 2005)

$$
D=\frac{C \cdot I R \cdot F E}{P}
$$

where $C$ is the concentration of $A$ s in the vegetable $(\mathrm{mg} / \mathrm{kg}))$, IR is the time consumption of the vegetable $(\mathrm{kg} / \mathrm{d})$, FE is the frequency of exposure and $P$ the average human body weight.

For potato ingestion, a daily intake of $138 \mathrm{~g}$ of this tubercle was considered with the mean concentration of $0.85 \mathrm{mg} / \mathrm{kg}$. The resulting average dose for an adult is $1.68 .10^{-3} \mathrm{mg} /(\mathrm{kg} \mathrm{d})$. For the intake of cabbage, a daily intake of $138 \mathrm{~g}$ of this vegetable was considered with an average concentration in As of $0.65 \mathrm{mg} / \mathrm{kg}$. The resulting average dose for an adult is $1.28 \cdot 10^{-3} \mathrm{mg} /(\mathrm{kg} \mathrm{d})$.

For local fish consumption, average consumption of $40.2 \mathrm{~g} / \mathrm{d}$ was considered with the estimated concentration of $162 \mu \mathrm{g} / \mathrm{kg}$. The reason for choosing this value results from the following: ATSDR recommends an average value for the general population in the USA of $20.1 \mathrm{~g} / \mathrm{d}$. Other higher values up to $170 \mathrm{~g} / \mathrm{d}$ (e.g. for subsistence fishermen) are recommended. In this case a value that is twice the recommendation for the general population of the USA was adopted, since fish consumption is Portugal is much higher. The per capita consumption in Portugal is $60 \mathrm{~kg} / \mathrm{year}$, i.e. 162 $\mathrm{g} / \mathrm{d}$. The resulting average dose for an adult is $8.96 .10^{-5}$ $\mathrm{mg} /(\mathrm{kg} . \mathrm{d})$.

An additive model was used to assess the mean total dose by ingestion, since no synergies between the various sources of ingestion were known. The mean total dose is thus $3.45 .10^{-3} \mathrm{mg} /(\mathrm{kg} \mathrm{d})$.

\section{Inhalation}

The assessment was based on the following model (ATSDR, 2005)

$$
\text { Dose }(\mathrm{mg} /(\mathrm{kg} \cdot \mathrm{d}))=\frac{\mathrm{CS} \cdot \mathrm{FR} \cdot \mathrm{CA} \cdot \mathrm{CR}}{\mathrm{p}}
$$

where CS is the As concentration in dust $(\mathrm{mg} / \mathrm{kg}$ dust), FR is the inhalable fraction of dusts, CA is the concentration of dust in the atmosphere $\left(\mathrm{kg}\right.$ dust $/ \mathrm{m}^{3}$ of air), CR is the daily volume of inhaled air $\left(\mathrm{m}^{3} / \mathrm{d}\right)$ and $P(\mathrm{~kg})$ is the average human body weight.

To assess the average dose of inhaled arsenic, the following values were adopted: CS (the average concentration in As) identical to that of the dust on the paths around the village of S. Francisco $(810 \mu \mathrm{g} / \mathrm{kg}=0,81$ $\mathrm{mg} / \mathrm{kg}$ ); FR (the inhalable fraction of dusts, grain size lower than $10 \mu \mathrm{m}$ ) 40\%; CA: (the average concentration of dust in the atmosphere, $30 \mu \mathrm{g} \mathrm{m}^{-3}$, or, $3.10^{-8} \mathrm{~kg}$ $\mathrm{m}^{-3}$ ), CR (the daily inhaled air volume with a rate of 20 $\mathrm{m}^{3} / \mathrm{d}$ with an exposure period of 9 hours daily, which corresponds to an inhaled air volume rate of $7.5 \mathrm{~m}^{3} / \mathrm{d}$ ).

In a conservative scenario, with a concentration of dust in the atmosphere of $30 \mu \mathrm{g} \mathrm{m}^{-3}$, with 9 hours of daily exposure, with a fraction of particles lower than $10 \mu \mathrm{m}$ of $40 \%$, the average inhalation dose assessed for arsenic is $1.04 .10^{-9} \mathrm{mg} /(\mathrm{kg} \mathrm{d})$, which is a fairly very low value.

\section{Dermal contact}

In this case the effective dose was estimated using the following equation (ATSDR, 2005)

$$
A D=\frac{C \cdot C F \cdot S A \cdot B F \cdot D F \cdot A B S \cdot S M \cdot E F \cdot E D}{\text { P.T }}
$$

where the symbols mean: AD: absorbed dose $(\mathrm{mg} /$ kg.d); CS: contaminant concentration in soil $(\mathrm{mg} /$ (/ $\mathrm{kg} \mathrm{d})$ ); CF: conversion factor $\left(10^{-6} \mathrm{mg} / \mathrm{kg}\right)$; SA: average superficial area of human body $\left(\mathrm{cm}^{2}\right)$; BF: Fraction of exposed skin area (\%); DF: dust adhesion $\left(\mathrm{mg} / \mathrm{cm}^{2}\right)$; ABS: absorption by the skin (\%); SM: soil matrix effect (\%); EF: exposure frequency (occurrences/day); ED: duration of exposure (day/year); P: human body weight (kg); T: 365 days/year.

Only the exposure resulting from the adhesion of dust particles on the skin was considered. The mean surface area of the body of $1,950 \mathrm{~cm}^{2}$ was considered, with $20 \%$ being exposed. In the adherence of dust on the skin, a very conservative value of $1 \mathrm{mg} / \mathrm{cm}^{2}$ was 
adopted, a value much lower than the $20 \mathrm{mg} / \mathrm{cm}^{2}$ normally used in many toxicological studies. This choice results from the recommendation made by Hoang (1992) which considers this amount as the most realistic. A 6\% skin absorption factor (ABS) was considered and an effect of the matrix of SM of $20 \%$ (i.e. only $20 \%$ of the contaminant is available for contact). A frequency of exposure of 2 occurrences/day during 156 days/year was also considered.

Despite the assumption of these low conservative values, a high estimate for the mean dose of dermal contact exposure was obtained: $0.025 \mathrm{mg} /(\mathrm{kg} \mathrm{d})$.

\section{Toxic risk}

Arsenic is toxic by ingestion and dermal contact, not by inhalation (US EPA, 2001, 1013 and 2014). The reference doses adopted by the EPA and denoted in the IRIS database for chronic and sub-chronic exposures were selected as toxicological parameters. The reference dose for the chronic ingestion $(\mathrm{mg} /(\mathrm{kg} \mathrm{d}))$ of arsenic is $3.10^{-4} \mathrm{mg} /(\mathrm{kg} \mathrm{d})$. As the calculated mean total dose is $4.1 \cdot 10^{-3} \mathrm{mg} /(\mathrm{kg} \mathrm{d})$ results in a toxicity index of 13.7, a very high value and much above the threshold of 1. For dermal contact, the reference dose is $1,23.10^{-}$ ${ }^{4} \mathrm{mg} /(\mathrm{kg} \mathrm{d})$. Since the average dose is fairly great, $2.5 .10^{-2} \mathrm{mg} /(\mathrm{kg} \mathrm{d})$, the resulting toxicity index is also extremely high -203.3 . The relevant values are summarised in Table 11.

\begin{tabular}{lccc}
\hline & Dose $(\mathrm{mg} / \mathrm{kg} \cdot \mathrm{d})$ & Reference Dose $(\mathrm{mg} / \mathrm{kg} \cdot \mathrm{d})$ & Toxicity Index \\
\hline Ingestion & $3.45 \mathrm{E}-03$ & $3.00 \mathrm{E}-04$ & 11.5 \\
Inhalation & $1.04 \mathrm{E}-09$ & & \\
Dermal Contact & 0.025 & $1.23 \mathrm{E}-04$ & 203.3
\end{tabular}

Table 11. Assessed doses and toxicity indexes of As.

Tabla 11. Dosis evaluadas e índices de toxicidad del As.

\section{Carcinogenic Risk}

The carcinogenic risk is calculated by multiplying the exposure dose $(\mathrm{mg} /(\mathrm{kg} \mathrm{d}))$ by the carcinogen potency factor $(\mathrm{kg} \mathrm{d} / \mathrm{mg})$. It results in a dimensionless number (risk) that represents the excess probability of contracting cancer resulting from the specific exposure compared to the general background probability. Permissible values are usually $10^{-6}$ ( 1 in a million) for the general public and $10^{-5}$ ( 1 in one hundred thousand) for occupational environments. The values contained in the IRIS database for chronic and sub-chronic exposure were adopted (US EPA, 2013). As for ingestion the carcinogen potency factor is $1.5 \mathrm{~kg} . \mathrm{d} / \mathrm{mg}$, resulting in an extremely high carcinogenic risk $-6.15 .10^{-3}$. For inhalation the carcinogen potency factor is $50 \mathrm{~kg} \mathrm{~d} /$ $\mathrm{mg}$, resulting in a very low carcinogenic risk $-5.2 .10^{-8}$. For dermal contact the slope factor is $3.66 \mathrm{~kg} . \mathrm{d} / \mathrm{mg}$, resulting in an extremely high carcinogenic risk 9.15.10-2 (Table 12).

\begin{tabular}{lccc}
\hline & Dose $(\mathrm{mg} / \mathrm{kg} \cdot \mathrm{d})$ & Reference Dose $(\mathrm{mg} / \mathrm{kg} \cdot \mathrm{d})$ & Toxicity Index \\
\hline Ingestion & $345 \mathrm{E}-03$ & $300 \mathrm{E}-04$ & 11.5 \\
Inhalation & $1.04 \mathrm{E}-09$ & & \\
Dermal Contact & 0025 & $123 \mathrm{E}-04$ & 2033
\end{tabular}

Table 12. Estimated doses and carcinogenic risk.

Tabla 12. Dosis estimadas y Riesgo carcinogénico.

One may conclude that the situation is very serious, either from the toxic or carcinogenic point of view, and the population is being affected by the exposure pathways of ingestion and by dermal contact, although not by inhalation. The cultivation and use of vegetables is the main source of exposure by ingestion, whilst exposure to dermal contact derives only from the existence of dust with high concentrations of arsenic.

\section{Alternative 2 - Catastrophic event - dam failure and flow failure}

As commented, a partial collapse of the dam would result in the release of $200,000 \mathrm{~m}^{3}$ of tailings in a short time interval of several hours, with a simultaneous release of $90,000 \mathrm{~m}^{3}$ of leachates, with an average concentration in As of $6,300 \mu \mathrm{g} \mathrm{I}^{-1}$, corresponding to a sudden release to the river of $567 \mathrm{~kg}$ of dissolved arsenic. This event would happen simultaneously with the collapse of the corresponding retaining structure, the sandy support wall. Keeping the same proportion between sludge and sands and silt found for the overall structure, the total volume of material released would be $328,000 \mathrm{~m}^{3}$. The cross-section of the river would increase to $30 \mathrm{~m}^{2}$ and the average flow velocity would become $1.5 \mathrm{~m} / \mathrm{s}$.

\section{Transport of leachates}

The advective-dispersive transport equation can represent the transportation of a contaminant by a watercourse

$$
\frac{\partial C}{\partial t}+v \frac{\partial C}{\partial z}=D \frac{\partial^{2} C}{\partial z^{2}}
$$

In this partial derivative equation (PDE), $C(z, t)$ represents the average concentration of arsenic in the river water that is variable with the distance of transport $(z)$ and in time $(t), v$ is the mean velocity of the river and $D$ is the longitudinal dispersion coefficient. $D$ was assessed by a numerical model, represented by the following equation (Iwasa and Aya, 1991)

$$
D=2 H U\left(\frac{B}{H}\right)^{1.5}
$$

where $U$ represents the average velocity of the river, $\mathrm{H}$ the depth and $\mathrm{B}$ its average width. As the disturbance is of the impulse type, the PDE can be easily solved. The solution is graphically represented in Figure 15. 


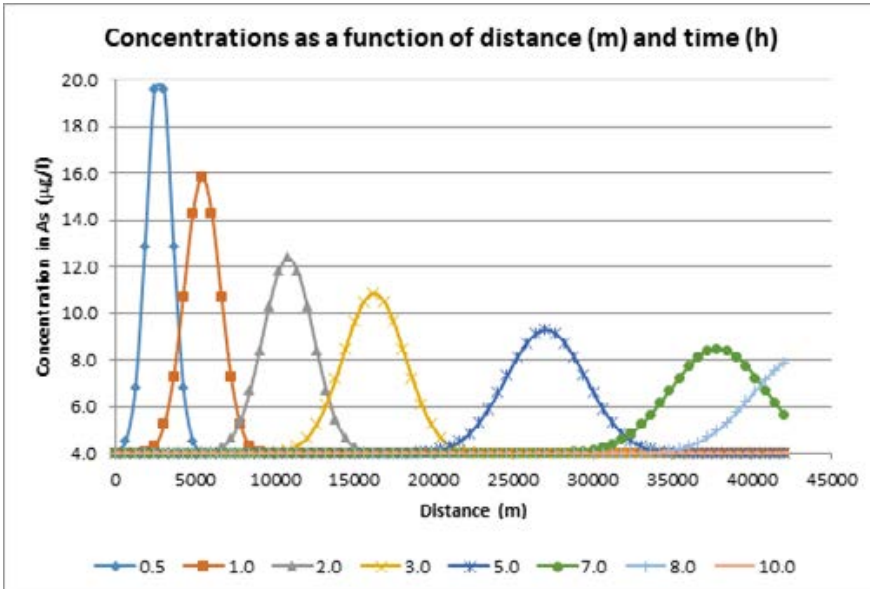

Figure 15. Concentrations in As as a function of distance and time. Figura 15. Concentraciones de As en función de la distancia y tiempo.

About 7.5 hours after the occurrence of the accident, the contamination, constituted by the dissolution of the leachates in the water of the river Zêzere, reaches the Cabril water dam. Concentrations higher than the water drinkability threshold $\left(10 \mathrm{\mu g} \mathrm{I}^{-1}\right)$ would affect the river in a length of about $12.5 \mathrm{~km}$, for 2 hours. The full transport of leachates to the Cabril water dam would take about 10 hours.

The river also carries solid particles. The distance travelled before sedimentation at the bottom of the river bed depends on the average flow velocity. Assuming the average values referred (depth of $1.6 \mathrm{~m}$ and river velocity of $1.5 \mathrm{~m} / \mathrm{s}$ ) the distance to which particles of different sizes are transported using a model for hindered settling (Major, 1978) was estimated.

The particles with the median size $(26 \mu \mathrm{m})$ would travel $2.7 \mathrm{~km}$ before settling, whilst the finer particles, for example with the size of $5 \mu \mathrm{m}$, would travel $72 \mathrm{~km}$. A particle of grain size $2 \mu \mathrm{m}$ would ideally travel $435 \mathrm{~km}$. Practically, all particles of size less than $8 \mu \mathrm{m}$ would reach the reservoir of the Cabril water dam. The coarser particles would settle along the bottom of the river and the banks. Considering the grain size distribution of the tailings, about $35 \%$ of the particles $\left(70,000 \mathrm{~m}^{3}\right)$ would settle in the reservoir whilst the remaining $65 \%$ $\left(130,000 \mathrm{~m}^{3}\right)$ would settle along the course of the river. Naturally, this $130,000 \mathrm{~m}^{3}$ of sludge would be accompanied by more $128,000 \mathrm{~m}^{3}$ of sand which constitutes the supporting structure of the dam.

Assuming that $258,000 \mathrm{~m}^{3}$ of tailings would settle along the course of the Zêzere river, before they reach the reservoir of the Cabril water dam, and that $50 \%$ would be deposited at the bottom of the river and the other $50 \%$ on the banks, the areas of land that would be covered by contaminated tailings would depend on the thickness of these sediments. Table 13 quantifies the areas that would have to be subsequently remediated.

\begin{tabular}{c|c}
\hline Thickness $(\mathrm{cm})$ & Deposition area (ha) \\
\hline 2 & 322.5 \\
\hline 5 & 129.0 \\
\hline 7 & 92.1 \\
\hline 10 & 64.5 \\
\hline 12 & 53.8 \\
\hline 15 & 43.0 \\
\hline
\end{tabular}

Table 13. Areas covered with tailings as a function of the average thickness.

Tabla 13. Zonas cubiertas de relaves en función del espesor medio.

The most probable mean values of deposition thickness would be between 5 and $10 \mathrm{~cm}$, involving a future necessity to collect this waste to rehabilitate the new dispersed contaminated area, from a surface between 65 and 129 hectares in an area difficult to reach, which would involve very expensive remediation logistics. In contrast, the concentration in As in the water of the reservoir, which supplies several collection points, would not exceed the limits of drinkability.

There is still the possibility of an occasional accident happening by submersion of people who were walking along the base of the slopes at the time of the accident. The population affected by the contamination would be much higher in this scenario, and there would be the creation of a new dispersed source of contamination.

\section{Conclusions}

The following conclusions should be highlighted:

- The storage of fine tailings of the Cabeço do Pião occupies a large volume (about 700,000 $\mathrm{m}^{3}$ ) of sludge with high concentrations in heavy metals. This storage is supported by compacted sands that constitute the support wall, totalling $1200,000 \mathrm{~m}^{3}$ of material;

- The element that occurs in the greatest concentration is arsenic with exceptionally high values, even in a global context (average concentrations of $15 \%)$. There are also relatively high concentrations of $\mathrm{Zn}(1.41 \%), \mathrm{Cu}(0.60 \%)$ and $\mathrm{W}(0.39 \%)$;

- The exceptionally high concentrations of arsenic exceed all the values set in the different regulations and legislations. Thus, the tailings contain substances or preparations classified as hazardous under Decree-Law No. 209/1999 of June 11, 1999 and Decree-Law No. 82/2003, of April 23, 2003 also exceed the values defined in the Canadian Environmental Quality Criteria for Contaminated Sites in Ontario adopted in Portugal and do not comply with the safety standards established in the Mining Waste Directive of the European Community.

- Furthermore, following the Commission Regu- 
lation (EU) No 1357/2014 of 18 December 2014, it is clear that there is the presence of a hazardous, carcinogenic residue (category $\mathrm{H} 7$ ) with priority category of intervention A.

- Arsenic is toxic and carcinogenic by all the exposure pathways (except inhalation) and is continuously released from the tailings embankment to the environment through two dispersive vectors: the leachates produced within the storage that is released on the slope of the hillside where the storage was built, and by wind action, since the storage has no coverage. Based on analyses made by various researchers in different environmental fields (surface water, groundwater, soils, dust, flora) and using a realistic exposure scenario it has been possible to develop a toxicological quantitative risk assessment using only arsenic as a contaminant, since this element is responsible for almost all of the total environmental impact.

- The inclusion of other elements would aggravate the situation, which is by itself, extremely serious.

- It was found that, in the toxic perspective, the local population is subject to environmentally unacceptable risks far exceeding the reference doses established by the IRIS database; this is happening for the exposure pathways by ingestion and dermal contact.

- From a carcinogenic perspective the risks obtained for any of the three routes of exposure, also including inhalation, are unacceptable and show that the population is subject to a much higher carcinogenic risk than the values established as being acceptable.

In the case of collapse of the embankment some hundreds of thousands of cubic metres of material will be released which in the case of heavy rains will form a pulp that will be transported by the Zêzere River to the water reservoir of the Cabril dam.

- As the material is extremely fine (the largest percentage lower than $74 \mu \mathrm{m}$ ), the sludge particles would be transported to the Cabril Reservoir, covering an area of enormous proportions, where the tailings will spread out.

- In this situation, a new dispersed environmental liability would be created in a hard-to-reach riparian area, affecting a considerably larger surface that will require extremely complicated and costly logistical efforts in terms of future rehabilitation. The affected population will increase substantially.

- Taking all of the above points into account it is clear that the site needs to be urgently rehabilitated, to drastically reduce the evidenced risks that are undoubtedly affecting the resident population. The possibility of a catastrophic scenario originated by a partial collapse of storage embankment may occur in an uncertain future, unless appropriate and urgent intervention measures are taken.

- In other words, there is already a continuous and real environmental and toxicological risk that affects the resident population. This risk will be multiplied if a catastrophic scenario of the embankment failure occurs.

\section{Acknowledgements}

This study is a component of the project REMINE that was funded with public national funds from Fundação para a Ciência e a Tecnologia FCT (Portugal) under the programme for International Cooperation ERA-NET, supported by ERA-MIN (2011-2015), funded under the EU $7^{\text {th }}$ Framework Programme FP7-NMP with partners from the Technical University of Luleå (Sweden) and the National Institute for Metals and Radioactive Resources (INCDMRR), Romania.

The authors gratefully acknowledge the support of the CERENA Research Center and Município do Fundão for their logistical and partial financial support.

\section{References}

Albuquerque T., Antunes I., Dinis M.L., Futuro A., Góis J., Leite A., Vila M., Figueiredo J., Fiúza A. 2017, "Improving Resource Efficiency and Minimize Environmental Footprint - a case study preliminary results", Mine Water and Circular Economy IMWA 2017, Lappeenranta, Finland, International Conference. 6 pages; http://hdl.handle.net/1822/48396.

ATSDR (Agency for Toxic Substances and Disease Registry), Public Health Assessment Guidance Manual 2005 Update.

Ávila, P.F., Ferreira da Silva, E., Candeias 2017. Environmental Geochemestry and Health, Issue 39, 565589. https://doi.org/10.1007/s10653-016-9834-0

Brown, S. 1985. Quantitative Risk Assessment of Environmental Hazards. Annual Review of Public Health. (6), 247-267.

Bundschuh, J., Carerera A.P., Litter M. I. 2007, Distribución del Arsénico en las Regiones Ibérica e Iberoamericana, Iberoarsan.

Candeias, Ca., Melo R.a, Ávila, P.F., Ferreira da Silva E., Salgueiro A.R., Teixeira, J.P. 2014. Heavy metal pollution in mine-soil-plant system in S. Francisco de Assis-Panasqueira mine (Portugal). Applied Geochemistry 44, 12-26. DOI: http://dx.doi.org/10.1016/j.apgeochem.2013.07.009

Candeias C. ${ }^{\text {, }}$ Silva E., Ávila P., Coelho P., Teixeira J. 2014. Mining activities in Panasqueira area: Impact and threats in ecosystems and human health in rural communities, Comunicações Geológicas 101, Especial II, 973-976, ISSN: 0873-948X; e-ISSN: 1647-581X.

Candeias C. ${ }^{c}$, Silva E., Paula F. Ávila and Teixeira J. 2014. Identifying Sources and Assessing Potential 
Risk of Exposure to Heavy Metals and Hazardous Materials in Mining Areas: The Case Study of Panasqueira Mine (Central Portugal) as an Example, Geo-Sciences, 4, 240-268. DOl: http://dx.doi. org/10.3390/geosciences4040240.

Candeias C., Ávila P.F., da Silva, E.F., et al. 2015. Water-Rock Interaction and Geochemical Processes in Surface Waters Influenced by Tailings Impoundments: Impact and Threats to the Ecosystems and Human Health in Rural Communities (Panasqueira Mine, Central Portugal). Water Air \& Soil Pollution, 226: 23. https://doi.org/10.1007/s11270-014-2255-8.

Codling E., Chaney R. and Green C.E. 2016. Accumulation of Lead and Arsenic by Potato Grown on LeadArsenate-Contaminated Orchard Soils. Communications in Soil Science and Plant Analysis, 47:6, 799-807, DOI: 10.1080/00103624.2016.1146754

Coastech Research Inc. 1989. Investigation of Prediction techniques for Acid Mine Drainage. MEND Project 1.16.1a. Canada Center for Mineral and Energy Technology, Energy, Mines, and Resources Canada. 61 pages

Comité Européen de Normalisation, EN 1097-4 2008. Tests for Mechanical and Physical Properties of Aggregates - Part 4: Determination of the Voids of Dry Compacted Filler

Dove PM, Rimstidt JD 1985. The solubility and stability of scorodite, $\mathrm{FeAsO} 42 \mathrm{H} 2 \mathrm{O}$. American Mineralogist 70, 838-844.

FAO/WHO, 2012. Food Additives and Contaminants. Codex Alimentarius Commission. Joint FAO/WHO Food Standards Programme 2001, ALINORM 01/12A 1-289.

Ferreira R., Ensinas M., Canelas R., Conde D., Ferreira E. 2012. Simulação Matemática de Sedimentos e da Qualidade da Água do Rio Zêzere entre Silvares e a Captação da EPAL na Albufeira de Castelo do Bode, CEHI DRO - Instituto Superior Técnico, UTL.

Ferreira da Silva E., Ávila P.F., Salgueiro A.R., Candeias C., Pereira H.G 2013. Quantitative-spatial assessment of soil contamination in S. Francisco de Assis due to mining activity of the Panasqueira mine (Portugal). Environmental Science and Pollution Research, 20, 7534-7549. DOI: http://dx.doi. org/10.1007/s11356-013-1495-2

Figueiredo J., Vila M.C., Góis J., Pavani Biju B., Futuro A., Martins D., Dinis M.L., Fiúza A. 2019. Bi-level depth assessment of an abandoned tailings dam aiming its reprocessing for recovery of valuable metals. Minerals Engineering 133, 1-9. https://doi. org/10.1016/j.mineng.2018.12.016

Figueiredo J.,Vila M.C., Fiúza A., Góis J., Futuro A., Dinis M.L., Martins D. 2019. A holistic approach in re-mining old tailings deposits for the supply of critical metals: a Portuguese case. Minerals 9, 638. DOI: 10.3390/min9100638. 2019

Fiuza A., Futuro A, Guimarães M. 2014. Arsenic Sorption by Iron-Based Sorbents (IBS). One Century of the Discovery of Arsenicosis in Latin America (1914-
2014), Arsenic in the Environment, 657-661. CRC Press Taylor and Francis Group, ISSN: 2154-6568.

Fjeld R., Eisenberg N., Compton K. 2007. Quantitative Environmental Risk Analysis For Human Health. John Wiley \& Sons, Inc.

Fowler B.A., Selene C.H., Chou J., Robert, Jones L., Dexter, Sullivan Jr W., Chen C.J. 2015, Handbook on the Toxicology of Metals (Fourth Edition), Chapter 28 - Arsenic, Volume II, 581-624, Academic Press.

Franco A., Vieira R., Bunting R. 2014, The Panasqueira Mine at a Glance, International Tungsten Industry Association, Newsletter June 2014.

Gama D., 2002. Geotechnical and laboratory study of the tailings in the River Zêzere waste heap. Beralt tin and wolfram report, Lisbon, Portugal:9.

Góis J., Dinis M.L., Soeiro J., Vila C., Fiúza A., Leite A., Futuro A., Figueiredo J., Martins D. 2018. Circular statistical models in the studies of the atmospheric dispersion of particles from mining tailings dams. Fourth International Symposium on Mining Safety Science and Engineering, Beijing.

Gonçalves A. 2014, Alterações Ambientais e Riscos Associados à Exploração Mineira no Médio Curso do Rio Zêzere. O Caso das Minas da Panasqueira. DoctoralThesis, Universidade de Coimbra.

Grangeia C., Ávila P., Matias M., Ferreira da Silva E. 2009. An integrated investigation of the Rio tailings - Panasqueira mine (Centre Portugal). LNEG. http:// hdl.handle.net/10400.9/767, 2009

Granjeia C., P. Ávila, M. Matias, Silva E. 2011. Mine tailings integrated investigations: The case of Rio tailings (Panasqueira Mine, Central Portugal), Engineering Geology 123, 359-372. DOI: 10.1016/j.enggeo.2011.10.001

Haque M., Hazrat A., Tuhin S. R., Masum S. and Chowdhury I. 2015. Yield reduction and arsenic accumulation in potatoes (Solanum tuberosum L.) in an arsenic contaminated soil. Journal of Plant Sciences, Volume 3, Issue 1, 31-44.

Hoang, K. T. 1992. Dermal Exposure Assessment: Principles and Applications. U.S. Environmental Protection Agency.

Iwasa, Y., \& Aya, S. 1991. Predicting longitudinal dispersion coefficient in open-channel flows. Proceedings of the international symposium on environmental hydraulics, Hong Kong, 505-510.

LaGrega M., Buckingham P., Evans Jeffrey 1984. Hazardous Waste Mangement. McGraw-Hill International Editions.

Lanhade K.R. 2013, Assessment of Heavy Metal Contamination in Vegetables Grown in and Around $\mathrm{Na}-$ shik City, Maharashtra State, India. IOSR Journal of Applied Chemistry (IOSR-JAC), ISSN: 2278-5736. Volume 5, Issue 3(Sep. -Oct. 2013), pp 09-14.

MacLean K.S. and Langille W. M. 1981. Arsenic In Orchard And Potato Soils And Plant Tissue. Plant and Soil 61: 413.

Mackay D. 2001. Multimedia Environmental Models: 
The Fugacity Approach. Lewis Publishers, 2nd Edition.

Major J.J. 1978. Hindered settling. In: Middleton G. V.In: Church M.J., Coniglio M., et al. (ed.) Encyclopedia of Sediments and Sedimentary Rocks. Springer.

Marta I.L, Cortina J.L., Fiúza A., Futuro A. and Tsakiroglou C 2014. In-situ technologies for groundwater treatment: the case of arsenic, In: Jochen Bundschuh et al. (ed.) In-Situ Remediation of Arsenic-Contaminated Sites. CRC Press, ISBN 9780415620857

Minasny, Mcbratney A.B., Rough O.M., Jacquier D. 2011. Models relating soil pH measurements in water and calcium chloride that incorporate electrolyte concentration. European Journal of Soil Science, October 2011, 62, 728- 732.

National Research Council 1983. Risk Assessment in the Federal Government: Managing the Process. National Academy Press, Washington D.C.

Noronha F., Dória A., Dubessy J., Charoy B. 1992. Characterisation and timing of the different types of fluids present in the barren and ore-veins of the W-Sn deposit of Panasqueira, Central Portugal. Mineralium Deposita, 27, 72-79.

Regulamento (UE) N.o 1357/2014 da Comisión. Diario Oficial de la Unión Europea.

Remine, Improve Resource Efficiency and Minimize Environmental Footprint 2019. Relatório Final -

Descrição detalhada das actividades desenvolvidas. Unpublished Report. Cerena Research Centre, FEUP.

Reis C. 1971. As Minas da Panasqueira, Boletim de Minas, Lisboa, 8 (I) Jan.-Mar., 3-44.

Rosário L. 2004. Indicadores de Desertificação para Portugal Continental. Direcção-Geral dos Serviços Florestais.

Sá C., Naique, R. A., Nobre, Edmundo 1999. Mina da Panasqueira - 100 anos de história mineira,. Boletim de Minas $n^{\circ} 36$ (1), 3-22.
Salom, Andreas 2017. Remining and Restructure of a Tailing Deposit - Technical Feasibility. Master Dissertation in Mining and Geo-Environmental Engineering. University of Porto, Faculty of Engineering. URL: http://hdl.handle.net/10216/105289.

Samanta G., Sharma R., RoychowdhuryT., Dipankar C. 2004. Arsenic and other elements in hair, nails, and skin-scales of arsenic victims in West Bengal, India. The Science of the total environment. 326. 33-47..

Silva N.M. 2010. Observações, Reflexões e Recomendações em Torno da Escombreira do Cabeço do Pião, Silvares, Fundão. Dissertation in Mining and Geo-Environmental Engineering . FEUP.

Thibodeaux L.J.. Environmental chemodynamics: Movement of chemicals in air, water and soil (2nd edition) 1996. John Wiley \& Sons, Inc, ISBN: 0-47161295-2

Trapp S., Matthies M. 1997. Chemodynamics and Environmental Modeling. Springer, ISBN: 3540630961

WHO 2001. Environmental health criteria 224: Arsenic and arsenic compounds, $2^{\text {nd }}$ Edition World Health Organization, Geneve, $186 \mathrm{p}$.

US EPA 2013. Integrated Risk Information System, Latest non-radioactive assessment list in Excel.

US EPA 2014. Framework for Human Health Risk Assessment to Inform Decision Making, 76 pages.

US EPA 1997, National Center for Environmental Assessment Office of Research and Development. Exposure Factors Handbook.

U.S. EPA 2001, Arsenic Exposure and Health Effects, Revised/edited by Ann Morgan

U.S. EPA 2014. IRIS Toxicological Review of Inorganic Arsenic (Preliminary Assessment Materials, 2014). U.S. Environmental Protection Agency, Washington, DC, EPA/630/R-14/101.

Wagner J.O., Mathies 1996. Guideline for Selection and Application of Fate and Exposure Models, Environmental Science and Pollution Research 3(1), 47-51.

Recibido: julio 2020

Revisado: diciembre 2020

Aceptado: enero 2021

Publicado: diciembre 2021 